\title{
TRT Kurumu'nun TRT Okul Kanalındaki Yayınlarının Ortaöğretim Biyoloji Dersi Öğretim Programı Kazanımları Açısından Analizi*
}

\author{
Ayşegül YILDIRIM1', Gülay EKİCİ ${ }^{2}$ \\ ${ }^{1}$ Türkiye Radyo Televizyon Kurumu, ayseglbiyik@hotmail.com \\ ${ }^{2}$ Doç. Dr., Gazi Üniversitesi Gą̧ Eğitim Fakültesi, Eğitim Bilimleri Bölümü, Eğitim Programlar ve Öğretim ABD, \\ gulayekici@yahoo.com
}

Geliş Tarihi/Received: 30.1.2016

Kabul Tarihi/Accepted: 9.5.2016

e-Yayım/e-Printed: 15.7.2016

DOI: http://dx.doi.org/10.14582/DUZGEF.712

\begin{abstract}
ÖZ
Bu araştırmanın temel amacı; Türkiye Radyo Televizyon Kurumu'nun TRT OKUL kanalında yayınlanan "Gerçek Hayatta Ne İssimize Yarayacak?” adlı programın ortaöğretim biyoloji dersi öğretim programının kazanımları açısından analiz etmektir. Araştırmada nitel model kapsamında durum çalışması deseni kullanılmışır. Çalışma grubunu 42 biyoloji alan uzmanı oluşturmaktadır. Veri toplama aracı olarak, MEB Ortaöğretim 9., 10., 11. ve 12. sınıf Biyoloji Dersi Kazanımlar Formları ve TRT'de Yayınlanan “Gerçek Hayatta Ne İşimize Yarayacak?” programı ile ilgili Değerlendirme Formu kullanılmıştır. Formların kodlayıcılar arasındaki ortalama uyum değerleri $\% 85$ ile \%92 arasında bulunmuştur. Toplanan verilerin değerlendirilmesinde betimsel istatistiksel işlemlerden frekans ve yüzde dağılımları hesaplanmıştır. Araştırmada elde edilen sonuçlar, "Gerçek Hayatta Ne İşimize Yarayacak?” adlı televizyon yayınının genel anlamda ortaöğretim 9., 10., 11. ve 12. sınıf biyoloji dersi öğretim programı kazanımlarını sağlamakta yetersiz kaldığı, ancak; programa ilişkin içerik, süre ve konunun işlenişine yönelik uzman değerlendirmelerinin olumlu yönde olduğu sonucuna varılmıştır.
\end{abstract}

Anahtar Kelimeler: Televizyon, kitle iletişim araçları ile eğitim, kamu hizmeti yayıncıllğı, TRT, biyoloji dersi öğretim programı.

\section{The Analysis of the Television Programs of Radio Television High Council of Turkey on TRT School Channel in Terms of Gains in Secondary Education Biology Course Curriculum}

\begin{abstract}
The main aim of the current study was to analyze the TV program that is called as "How does it serve in real life?" of Radio and Television High Council of Turkey on TRT School Channel in terms of gains in secondary school biology course curriculum. This research was designed in the case study method which is one of the qualitative research approaches. The data collection tools were applied to 42 domain experts in biology. As a data collection tool, the 9th, 10th, 11th and 12th Grades Biology Course Curriculum Gains Form of Ministry of Education and the Evaluation Form related to "How does it serve in real life?" program of TRT School channel were developed. The inter-rater reliability coefficient of the instruments varied between $85 \%$ and $92 \%$. In data analysis, descriptive statistics were used, the frequencies and percentage distribution were calculated, and in light of this information, the findings and results were assessed. The findings of the current study showed that, "How does it serve in real life?" program failed to satisfy the gains of secondary education 9th, 10th, 11th, and 12th grades biology course curriculum. However, the evaluations of domain experts in terms of the content, timing, and discussion of the subjects of the TV program were positive.
\end{abstract}

Key words: Television, media and education, public service broadcasting, TRT, biology curriculum.

\footnotetext{
* Bu çalışma ilk yazarın ikinci yazar danışmanlığında hazırladığı yüksek lisans tezinden hazırlanmıştır.
} 


\section{GİRİŞ}

Geçmişten günümüze birçok değişiklik, çeşitlilik ve gelişme gösteren iletişim araçlant, kitle olgusunun ortaya çıkması ile kitle iletişim araçlarına dönüşmeye başlamıştır. İnsanlar ilk çağlarda dumanla, daha sonra çeşitli kanatlı hayvanlarla ve elçilerle haberleşmekteydi. İlkel özellikler gösteren iletişim araçları daha sonraları büyük değişimlere uğramıştır. Günümüze yaklaşıldıkça posta, sanayi devrimi ve elektriğin icadı ile de telefon ve telgraf gibi teknolojik araçların geliştirildiği görülmektedir. Teknolojinin gelişmesi ile iletişim araçları günümüzde daha da modern hale gelmiştir. Kitle iletişim araçları sayesinde insanlar eğlenmekte, bilgi edinmekte ve birçok konudan anında haberdar olmaktadırlar. İnsanların yaşamlarını etkileyen pek çok kitle iletişim araçları, sosyal yaşamda ekonomi, siyaset ve eğitim gibi birçok konuyu da etkilemektedir (Karataş, 2010). Bu kapsamda eğitimdeki teknolojik gelişme, eğitimin içeriğini, biçimini, yayın alanını ve öğrenmenin hızını etkilemektedir. Toplumların klasik eğitimin uygulamalarında kitle iletişim araçlarından görsel ve işitsel olanları çok önemlidir. Kitle iletişim araçları içerisinde klasik olan radyo, televizyon, sinema ve yazılı materyaller, genelde günümüzde uzaktan öğrenme ile öğrencileri eğitmek için ilk, orta, lise ve üniversitelerde sık kullanılan araçlar arasında yer almaktadır. Ayrıca internet, uydu ve televizyon gibi uzaktan eğitimde kullanılan birçok araç da bulunmaktadır (Varol, 1997).

Günümüzün en yaygın kitle iletişim araçlarından biri olan televizyon, bireylere gerçek ve sanal dünyayı izleyiciler ile paylaşırken, görsel ve işitsel uyaranlar ile renkli bir atmosferde sunmaktadır. Dünyaya açılan bir çeşit pencere olan ve insanları etkileme gücü yüksek olan televizyon birçok araştırmaya konu olmuştur. Televizyon evrensel bir araç olmasına rağmen, her toplumda ve her kültürde farklı etkilere sahiptir. Ülkemize ise son zamanlarda televizyon fiyatlarının her bütçeye uygun hale gelmesi, özel kanalların çoğalması ve yayınların çeşitlenmesi gibi faktörler, televizyonun bireyler üzerindeki etkilerinin artmasını desteklemektedir (Atay ve Öncü, 2006).

Televizyondaki eğitim yayınları incelendiğinde ise, televizyonun haber ve bilgi vermeye yönelik programları "tamamlaync eğitim”, meslekler ile ilgili bilgi ve becerileri aktaran, teknolojik gelişmelere ve gelişmelerin sonucunda ortaya çıkan duruma uyum göstermeye yardımcı olan, bireyin ufkunu genişletmeyi amaçlayan, bireylerin ufkunu genişletmeyi amaçlayan programlar ise "yaygzn eğitim” kapsamına girmektedir. Televizyonun eğitim açısından önemli bir yere ve öneme sahip olması, televizyonun bireyin birden fazla duyu organını uyararak algılaması, hafızada tutma ve öğrenmede kolaylık sağlaması ve bireyde öğrenme isteği uyandırması diğer kitle iletişim araçları ile karşılaştırıldığında televizyonu üstün ve etkili duruma getirmektedir (Aziz, 1982).

Türkiye'de ilk defa 1968 yılında yayına başlayan televizyon, sadece iletişim işlevine değil, yaygın ve tamamlayıcı eğitim anlayışını benimseyen, izleyiciyi eğitme fonksiyonunu da yerine getiren programlara yer verildiği görülmektedir. Eğitici yayınların bir kısmı, yabancı dil yayınları, trafik, çevre ve sağlık, beslenme, giyim, spor, el sanatları, çocuk bakımı, köy yaşantısı, köyün sorunları ile ilgili yetişkinlere hitap eden, genel bilgi veren ve günlük yaşantıda uygulanabilecek becerileri ve etkinlikleri öğreten programlardan oluşmaktadır. 1981-1982 yıllarında, "TV Okulu” adıyla yayınlanan bir program dizisi, örgün eğitim görmemiş yetişkinlere okuma-yazma öğretmek amacıyla yayınlanmıştır (Aziz, 1975; Aziz, 1982; Özgen, 
1985). Bu kapsamda Türkiye'de ilk TV yayını İstanbul Teknik Üniversitesi tarafından 9 Temmuz 1952 günü gerçekleştirilmiştir. Daha sonra 31 Ocak 1968'de TRT kurulur ve TRT’nin tek kanalından yayınlanan programlar topluca ve yayın bitene kadar seyredilir. Radyo ve televizyon yayınları yıllarca TRT'nin tekelindedir. 1980’lerin sonunda ise özel televizyonlar ortaya çımıştır (Turam, 1996).

Günümüzde ise artık her evde televizyonun bulunmasının yanı sıra evdeki televizyon sayısı giderek artmıştır. Televizyon kanalları da her geçen gün daha da artmakta ve programlar farklılaşmaktadır. Tutum oluşumu ve gelişiminde, yaşantımızın önemli bir alanına giren ve evin vazgeçilmez bir parçası olan televizyon; aile, arkadaş, okul gibi çevresel değişkenler arasında üst sıralarda yer almaktadır. Erken yaşlarda geliştiği bilinen tutumların ve davranışların kazanılmasında, başta televizyon olmak üzere pek çok kitle iletişim aracının etkinliğinden söz etmek mümkündür (Ertürk ve Akkor, 2006). Bu araştırma, TRT OKUL kanalında yayınlanan eğitim programlarının MEB'in hazırladığı öğretim programlarında belirlenmiş olan kazanımlara ulaşmasında ne derecede uygun olduğunun incelenmesi açısından önem arz etmektedir. İlgili literatür araştırması sonucunda bu konuda yapılmış hiçbir araştırmaya rastlanmamıştır. Bu genel önemin yanında, ayrıca aşağıda belirtilen noktalarda da bu araştırma verilerinin alana önemli katkılar sağlayacağı umulmaktadır.

1. Biyoloji dersinde öğrencinin başarılı olabilmesi yönünde TRT OKUL kanalında yayınlanan programların öneminin vurgulanmasında etkili olacağı,

2. Biyoloji dersi kazanımlarının istenilen düzeyde ortaya çıkmasında TRT OKUL kanalında yayınlanan programların öneminin vurgulanmasında etkili olacağı,

3. Program yapımcılarının hazırlıklarında MEB öğretim programında belirtilen kazanımları dikkate almasında etkili olacağı düşünülmektedir.

\subsection{Araştırmanın Amacı}

Araştırmanın genel amacı, uzman görüşlerine göre TRT OKUL kanalında yayınlanan "Gerçek Hayatta Ne İşimize Yarayacak?” adlı televizyon yayınını ortaöğretim biyoloji dersi öğretim programı kazanımları açısından analiz etmektir. Bu kapsamda, şu sorulara cevap aranmıştır;

1. Uzmanların "Gerçek Hayatta Ne İşimize Yarayacak?” adlı televizyon yayınının biyoloji dersi öğretim programının kazanımlarına uygunluğuna yönelik görüşleri nelerdir?

2. Uzmanların TRT de yayınlanan "Gerçek Hayatta Ne İşimize Yarayacak?” adlı eğitim programının içeriği, süresi ve konunun işlenişi ile ilgili görüşleri nelerdir?

\section{YÖNTEM}

Bu bölümde araştırmanın modeli, çalışma grubu, araştırmada kullanılan veri toplama araçlarının özellikleri ve verilerin analizi bölümleri açıklanmıştır.

\subsection{Araştırmanın Modeli}

$\mathrm{Bu}$ araştırma nitel araştırma modeline dayalı durum çalışması olarak desenlenmiştir. Durum çalışması, bir olguyu kendi gerçek yaşam çerçevesi içinde çalışan ve durumları çok yönlü, sistemli ve derinlemesine inceleyen görgül bir araştırma desenidir (Cohen ve Manion, 1997; McMillan, 2000; Patton, 1990; Yıldırım 
ve Şimşek, 2006). Durum çalışması, durumun sınırlanması, araştırma olgusunun belirlenmesi, veri setinin araştırılması, bulguların oluşturulması, yorumların yapılması ve sonuçların yazılması aşamalarını içerir (Denzin ve Lincoln, 1996; Bassey, 1999). Bu çalışmada da, biyoloji eğitimi alanında uzmanların TRT OKUL kanalında yayınlanan "Gerçek Hayatta Ne İşimize Yarayacak?” adlı programın ortaöğretim biyoloji öğretim programı kazanımlarına uygunluğuna yönelik görüşleri durum çalısmasıyla tespit edilmiştir.

\section{2. Çalışma grubu}

Nitel araştırma yöntemleri temel alınarak oluşturulan çalışmalarda araştırmacının amacı sonuçları tüm evrene genellemek değil ana problemi derinlemesine incelemektir. Bu yüzden araștırılan konunun daha iyi anlaşılması için araştırmacı amaçlı ya da isteyerek katılımcıları, çalışma grubunu belirler (Creswell, 2012). Bir araştırmada gözlenecek durum belirli niteliklere sahip olaylar, kişiler ve durumlardan oluşabilir. $\mathrm{Bu}$ durumda örneklem için belirlenen ölçütü karşılayan birimler (nesneler, olaylar vb) örnekleme alınırlar (Büyüköztürk, Çakmak, Akgün, Karadeniz ve Demirel, 2008). Bu araştırma biyoloji eğitimi alanında uzman toplam 42 katılımcıyla hazırlanmıştır. Gönüllülük esasına göre cevaplanması istenen veri toplama araçlarının, biyoloji konularında uzman olan üniversitelerin fen ve edebiyat fakültelerinin biyoloji bölümü, eğitim fakültelerinin biyoloji öğretmenliği ve fen ve teknoloji öğretmenliği mezunlarına uygulanması planlanmıştır. Konu hakkında detaylı verilerin toplanması gerektiği, verilerin niteliğinin yüksek olması, uzmanların biyoloji eğitimi alanında çalışıyor olmaları, "Gerçek Hayatta Ne İşimize Yarayacak?” programını dikkatli ve özveriyle izleyebilecek, vakit ayırabilecek ve dolayısıyla araştırmaya katılmaya gönüllü olan uzmanların katılması gerektiği gibi nedenlerden dolayı, bu araştırmada amaçlı çalışma grubu seçilmiştir (Coyne, 1997; Given, 2008; Patton, 1990). "Gerçek Hayatta Ne İşimize Yarayacak?” programının biyoloji dersi öğretim programı kazanımlarına ne kadar ulaşabilmeyi sağladığı ile ilgili uzmanların görüşlerini belirlemek amacı ile yaklaşık 100 uzman ile iletişim kurulmuştur. Ancak toplam 42 uzmanın göndermiş olduğu formlar değerlendirmeye alınmıştır.

\subsection{Veri Toplama Araçları}

Araştırmada veri toplama araçları olarak yapılandırılmış ve yarı yapılandırılmış formlar kullanılmıştır. Bu formlar tanıtılmadan önce aşağıda TRT OKUL adlı eğitim kanalında yayınlanan "Gerçek Hayatta Ne İşimize Yarayacak?” programı hakkında bilgi verilmiştir. Bu açılamalar ışığında veri toplama araçlarının detaylarının verilmesi daha anlamlı olacaktır.

\subsection{1. “Gerçek Hayatta Ne İşimize Yarayacak?” Programının Özellikleri}

“Gerçek Hayatta Ne İşimize Yarayacak?” programında sunucu, üniversite yerleşkesinde öğrencilere

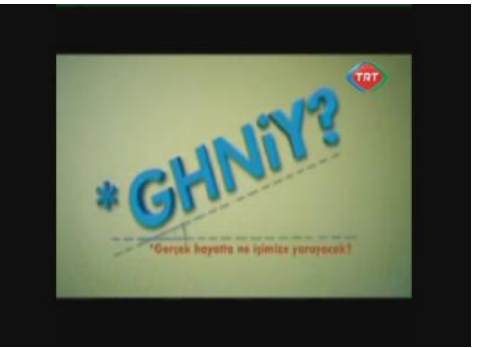
mikrofon uzatıp "Gerçek hayatta bu ne işimize yarayacak dediğin hangi konular oldu?” sorusunu yöneltmektedir. Programda, öğrencilerin verdiği cevaplar doğrultusunda en çok tekrarlanan konular belirlenmektedir. Ele alınan bu konular, uzmanlar tarafindan detaylıca açıklanmaktadır. “Gerçek Hayatta Ne İşimize Yarayacak?” programında fizik, kimya, biyoloji, matematik, edebiyat, tarih gibi alanlardaki konular 
işlenmektedir. Programın her bölümü 20 dakika sürmekte ve her bölümde dört farklı konu yayınlanmaktadır. TRT OKUL kanalında toplam 26 bölüm olarak yayınlanan "Gerçek Hayatta Ne İşimize Yarayacak?” eğitim yayınının ilk bölümü 1 Şubat 2011 tarihinde, 26. Bölüm ise 3 Ocak 2012 tarihinde ekranlara gelmiştir. Bu araştırmada, “Gerçek Hayatta Ne İşimize Yarayacak?” programının 13 bölümünde sunulan biyoloji konuları incelenmektedir. Her bir bölümde yer alan biyoloji konularına Tablo 1'de yer verilmektedir.

Tablo 1. "Gerçek Hayatta Ne İşimize Yarayacak?” Programının Araştırma Kapsamında Yer Alan 13 Bölümündeki Biyoloji Konularının Dağılımı

\begin{tabular}{|c|c|}
\hline 1. Bölüm & Nükleik Asitler \\
\hline 2. Bölüm & Bakteriler \\
\hline 3. Bölüm & Biyolojizle ilgili konи mеvсиt değil. \\
\hline 4. Bölüm & Fotosentez \\
\hline 5. Bölüm & Antioksidanlar \\
\hline 6. Bölüm & Biyolojiyle ilgili konu mevcut değil. \\
\hline 7. Bölüm & Keratin \\
\hline 8. Bölüm & Genetik, Selüloz \\
\hline 9. Bölüm & Kalsiyum \\
\hline 10. Bölüm & Mikroorganizma \\
\hline
\end{tabular}




\begin{tabular}{ll}
\hline 11. Bölüm & $\begin{array}{l}\text { Çinko, } \\
\text { İyot, } \\
\\
\end{array}$ \\
& Protein \\
\hline 12. Bölüm & Biyolojiyle ilgili konu mevcut değil. \\
\hline 13. Bölüm & Biyolojiyle ilgili konu mevcut değil. \\
\hline
\end{tabular}

Değerlendirilmek üzere alınan toplam 13 bölümlük "Gerçek Hayatta Ne İşimize Yarayacak?” programının 3., 6., 12. ve 13. bölümlerinde biyoloji alanıyla ilgili bir sunumun olmadığı tespit edilmiştir. Dolayısıyla çalışma toplam 9 bölüm üzerinden hazırlanmıştır. TRT ile Anadolu Üniversitesi işbirliğiyle kurulan ve 31 Ocak 2011"de yayın hayatına başlayan "Gerçek Hayatta Ne İşimize Yarayacak?” programının ekranlara getirildiği TRT OKUL kanalında, her yaştan insana hitap eden eğitim programlarının yanı sıra gençlere yönelik farklı program türlerine de yer verilmektedir. Bu araştırmada “Gerçek Hayatta Ne İşimize Yarayacak?” programı tercih edilmiştir. Çünkü içerik olarak bu program biyoloji eğitimine (fen eğitimine) uygun bilgiler vermeye yönelik olarak hazırlanmıştır. TRT OKUL kanalında seyirciler ile buluşan “Gerçek Hayatta Ne İşimize Yarayacak?” eğitim programının 20'şer dakikalık fizik, kimya, biyoloji, edebiyat, matematik vb. konulardan oluşan 13 bölümündeki her bir biyoloji konusu alınarak yaklaşık bir saatlik (56 dk.) tek bir bölümlük video haline getirilmiştir. Bu sayede, uzmanların daha hızlı ve zamandan tasarruflu bir şekilde bu videoyu izlemeleri ve hazırlanan ölçme araçlarına en uygun şekilde cevapları vermeleri hedeflenmiştir.

\subsubsection{Veri Toplama Araçlarının Hazırlanması}

Araştırmada kullanılan veri toplama formları hakkında detaylı bilgilere aşağıda yer verilmektedir.

\subsubsection{MEB Ortaöğretim Biyoloji Dersi Öğretim Programı Kazanımlar Formları}

“Gerçek Hayatta Ne İşimize Yarayacak?” adlı programın ortaöğretim biyoloji dersi öğretim programı kazanımlarını sağlamada ne kadar etkin olduğunu belirlemek amacıyla ortaöğretim biyoloji dersi öğretim programının 9., 10., 11. ve 12. sınıf biyoloji dersi ünitelerinin kazanımları alınarak "MEB Ortaöğretim 9. Sınıf Biyoloji Dersi Kazanımlar Formu”, "MEB Ortaöğretim 10. Sınıf Biyoloji Dersi Kazanımlar Formu”, "MEB Ortaöğretim 11. Sınıf Biyoloji Dersi Kazanımlar Formu" ve "MEB Ortaöğretim 12. Sınıf Biyoloji Dersi Kazanımlar Formu" her bir sınıf için ayırı ayrı hazırlanmıştır.

Hazırlanan formlarda her bir kazanım "Uygun”, "Kısmen Uygun” ve "Uygun Değil” seçeneklerinin yer aldığı 3'lü Likert Tipi maddeler şeklinde düzenlenmiştir. 9. sınıf Formunda 30 kazanım yer alırken, 10. sınıf Formunda 24, 11. sınıf Formunda 37 ve 12. sınıf Formunda 47 madde olmak üzere hazırlanan ölçme araçlarında toplam 138 madde yer almaktadır. Veri toplama araçlarının hazırlandığı ve verilerin toplandığ1 süreçte 2007-2011 yılları arasında yayımlanan biyoloji dersi öğretim programı yürürlükte olduğu için araştırmadaki ölçme araçları önceki ortaöğretim biyoloji dersi öğretim programına göre hazırlanmıştır. 


\subsubsection{TRT'de Yayınlanan “Gerçek Hayatta Ne İşimize Yarayacak?” Programı İle İlgili}

\section{Değerlendirme Formu}

"Gerçek Hayatta Ne İşimize Yarayacak?” adlı televizyon programı hakkında uzmanların düşüncelerini belirlemek için; içerik, süre ve konunun işlenişi başlıklarını içeren "TRT'de Yayınlanan Gerçek Hayatta Ne İşimize Yarayacak?” Programı İle İlgili Değerlendirme Formu düzenlenmiştir. Uzmanların, "Gerçek Hayatta Ne İşimize Yarayacak?” eğitim yayını ile ilgili genel görüşlerini belirlemek amacıyla açık uçlu sorular sorulmuştur. Bu sorular aşağıda belirtildiği şekilde düzenlenmiştir:

TRT’de yayınlanan “Gerçek Hayatta Ne İşimize Yarayacak?” eğitim programının;

-içeriği,

-süresi,

-konunun işlenişi ve

-diğer görüş ve önerilerinizi yazınız.

Yukarıda belirtilen formlar hazırlandıktan sonra geçerlik yönünden değerlendirmeleri açısından iki alan uzmanı, iki ölçme ve değerlendirme alan uzmanı olmak üzere toplam dört uzman görüşüne sunulmuştur. Görüşler yönünde uygun şekilde düzenlenen formalara son şekli verilmiştir. Daha sonraki süreçte bu formlar iki alan uzmanından "Gerçek Hayatta Ne İşimize Yarayacak?” programını izleyerek cevaplamaları istenmiştir. Doldurulan formların “Gerçek Hayatta Ne İşimize Yarayacak?” programının değerlendirilmesine uygunluğuna yönelik olarak iki uzmanın görüşleri yönünde kodlayıcılar arasındaki ortalama güvenirlik değerleri hesaplanmıştır. Bu şekilde yapılan güvenirlik değeri hesaplanmasında; [Görüş birliği / (Görüş birliği + Görüş ayrılloğ1) x 100] formülü kullanılmıştır (Miles ve Huberman, 1994). Böylece doldurulan formaların kodlayıcılar arasındaki ortalama güvenirlik değerleri hesaplanmıştır. Buna göre 9 . sınıf formu için bu değer $\% 85$ olarak hesaplanırken, 10 . sınıf formu için bu değer $\% 88$, 11. sınıf formu için bu değer $\% 92$ ve 12 . sınıf formu için bu değer $\% 90$ olarak hesaplanmıştır.

\subsection{Verilerin Toplanmas1}

Uzmanlara videoların ve ilgili görüş belirtme formlarının ulaştırılması ve onlardan geri alınması oldukça zorlu bir süreç olmuştur. Bu süreçte uzmanların izledikleri "Gerçek Hayatta Ne İşimize Yarayacak?" programının videosu ve dolduracakları ölçme araçları iki farklı şekilde uzmanlara ulaştırılmışır. Video, uzmanlardan bazılarına, "wetransfer" adlı dosya paylaşımına imkan sağlayan internet sayfasına yüklenmiş ve videonun yüklendiği bu adres uzmanların videoyu internetten kendi bilgisayarlarına yükleyebilecekleri şekilde uzmanlara gönderilmiştir. Ölçekler elektronik posta yolu ile gönderilirken, diğerlerine ise video, DVD ortamında ve ölçeklerde kağıda basılı bir şeklinde ulaştırılmıştır. Uzmanların yanıtladıkları formların elektronik posta yolu ile ya da kağıda basılı ölçeklerin üzerine işaretlenmişs şekilde araştırmacıya ulaştırmaları sağlanmıştır.

\subsection{Verilerin Analizi}

Araştırma kapsamında kullanılan ölçme araçlarında yer alan maddelerin tek tek toplanıp ve üzerinde herhangi bir işlem yapılmadan verilerin daha anlaşılır olması amacı ile frekans (f) ve yüzde (\%) dağılımları bulunmuş ve bulgular bölümünde tablo haline getirilerek yorumlanmıştır. Veri toplama aracı olarak 
geliştirilen “MEB Ortaöğretim 9. Sınıf Biyoloji Dersi Kazanımlar Formu”, "MEB Ortaöğretim 10. Sınıf Biyoloji Dersi Kazanımlar Formu”, “MEB Ortaöğretim 11. Sınıf Biyoloji Dersi Kazanımlar Formu” ve “MEB Ortaöğretim 12. Sınıf Biyoloji Dersi Kazanımlar Formu” ve “TRT’de Yayınlanan Gerçek Hayatta Ne İşimize Yarayacak? Programı İle İlgili Değerlendirme Formu” adlı ölçeklerin analizinde betimsel analiz teknikleri kullanılmıştır. Veriler çözümlenirken frekans (f) ve yüzde (\%) dağılımları hesaplanmıştır (Bilgin, 2006; Lichtman, 2010). Ayrıca uzmanların görüşlerinden örnekler verilirken U2, U17... şeklinde uzmanların numaraları belirtilmiştir.

\section{BULGULAR}

$\mathrm{Bu}$ bölümde elde edilen veriler her bir sınıf düzeyindeki kazanımlara ait görüşler yönünde değerlendirilmiştir. Buna göre uzman görüşlerine göre TRT’de yayınlanan “Gerçek Hayatta Ne İşimize Yarayacak?” programının MEB Ortaöğretim 9. 10. 11. ve 12. Sınıf Biyoloji Dersi Öğretim Programı kazanımlarına uygunluğuna ilişkin bulgular frekans (f) ve yüzde (\%) dağılımları şeklinde düzenlenmiştir (Tablo 2, 3, 4, 5). Ayrıca Uzmanların görüşlerinden alıntılara yer verilmiştir.

Tablo 2. Uzman Görüşlerine Göre TRT’de Yayınlanan “Gerçek Hayatta Ne İşimize Yarayacak?” Programının MEB Ortaöğretim 9. Sınıf Biyoloji Dersi Öğretim Programı Kazanımlarına Uygunluğuna İlişkin Bulgular

\begin{tabular}{|c|c|c|c|c|c|c|}
\hline \multirow{3}{*}{ 9. Sinıf Kazanımları } & \multicolumn{6}{|c|}{ Kismen } \\
\hline & \multicolumn{2}{|c|}{ Uygun } & \multicolumn{2}{|c|}{ Uygun } & \multicolumn{2}{|c|}{ Uygun Değil } \\
\hline & f & $\%$ & f & $\%$ & f & $\%$ \\
\hline $\begin{array}{l}\text { 1.Bir hücre üzerinden canlıların ortak özelliklerini } \\
\text { açılar. }\end{array}$ & - & - & 20 & 47,6 & 22 & 52,4 \\
\hline $\begin{array}{l}\text { 2.Canlıların yapısını oluşturan inorganik ve organik } \\
\text { bileşiklerin yapı ve görevlerini belirtir. }\end{array}$ & 12 & 28,6 & 30 & 71,4 & - & - \\
\hline $\begin{array}{l}\text { 3.Hücreye ilişkin çalışmaları tarihsel süreç içerisinde } \\
\text { değerlendirir }\end{array}$ & - & - & 16 & 38,1 & 26 & 61,9 \\
\hline 4.Hücrenin yapısını ve bu yapıların görevlerini açıklar. & - & - & 13 & 31,0 & 29 & 69,0 \\
\hline $\begin{array}{l}\text { 5.Hücre zarından madde geçişinin nasıl gerçekleştiğini } \\
\text { örneklerle açıklar. }\end{array}$ & - & - & 5 & 12,0 & 37 & 88,0 \\
\hline $\begin{array}{l}\text { 6.Prokaryot ve ökaryot hücreleri karşılaştırarak bunlara } \\
\text { örnekler verir. }\end{array}$ & - & - & 19 & 45,2 & 23 & 54,8 \\
\hline $\begin{array}{l}\text { 7.Bitki ve hayvan hücresini mikroskopta inceleyerek } \\
\text { karşılaştırır. }\end{array}$ & - & - & 6 & 14,3 & 36 & 85,7 \\
\hline $\begin{array}{l}\text { 8.Tek hücreli, koloni oluşturan ve çok hücreli } \\
\text { organizmalarda hücresel organizasyonu ve özelleşmeyi } \\
\text { örneklerle açıklar. }\end{array}$ & - & - & 20 & 47,6 & 22 & 52,4 \\
\hline $\begin{array}{l}\text { 9.Yakın çevresindeki gözlemlerinden yararlanarak } \\
\text { canlıların çeşitliliğini fark eder. }\end{array}$ & - & - & 24 & 57,1 & 18 & 49,9 \\
\hline 10.Canlıları bilimsel sınıflandırmanın önemini açıklar. & - & - & 18 & 42,9 & 24 & 57,1 \\
\hline $\begin{array}{l}\text { 11.Organizmaların ikili adlandırılmasının gerekliliğini } \\
\text { örneklerle açıklar. }\end{array}$ & - & - & - & - & 42 & 100,0 \\
\hline 12.Canlıları sınıflandırma kriterlerini belirtir. & - & - & 10 & 23,8 & 32 & 76,1 \\
\hline $\begin{array}{l}\text { 13.Canlıları sınıflandırmada kullanılan kategorilerin } \\
\text { belirli bir hiyerarşiyi yansıttığını fark eder. }\end{array}$ & - & - & 10 & 23,8 & 32 & 76,1 \\
\hline $\begin{array}{l}\text { 14.Bakteria, Arkea, Protista, Bitkiler, Mantarlar ve } \\
\text { Hayvanlar olarak } 6 \text { âlem altında sinıflandırıldığını } \\
\text { belirtir. }\end{array}$ & 14 & 33,4 & 20 & 47,6 & 8 & 19,0 \\
\hline
\end{tabular}




\begin{tabular}{|c|c|c|c|c|c|c|}
\hline $\begin{array}{l}\text { 15.Verilen bir teşhis anahtarını kullanarak yakın } \\
\text { çevresindeki bir organizmayı teşhis eder. }\end{array}$ & - & - & 10 & 23,8 & 32 & 76,2 \\
\hline $\begin{array}{l}\text { 16.Bakteria âleminin genel özelliklerini belirterek } \\
\text { örnekler verir. }\end{array}$ & 19 & 45,2 & 16 & 38,1 & 7 & 16,7 \\
\hline $\begin{array}{l}\text { 17.Arkea âleminin genel özelliklerini belirterek örnekler } \\
\text { verir. }\end{array}$ & 2 & 4,8 & 8 & 19,0 & 32 & 76,2 \\
\hline $\begin{array}{l}\text { 18.Protista âleminin genel özelliklerini belirterek } \\
\text { örnekler verir. }\end{array}$ & - & - & 7 & 16,7 & 35 & 83,3 \\
\hline $\begin{array}{l}\text { 19.Bitkiler âleminin başlıca alt gruplarının genel } \\
\text { özelliklerini belirterek örnekler verir. }\end{array}$ & - & - & 12 & 28,6 & 30 & 71,4 \\
\hline $\begin{array}{l}\text { 20.Mantarlar âleminin genel özelliklerini belirterek } \\
\text { örnekler verir. }\end{array}$ & - & - & 4 & 9,5 & 38 & 90,5 \\
\hline $\begin{array}{l}\text { 21.Hayvanlar âleminin başlıca alt gruplarının genel } \\
\text { özelliklerini belirterek örnekler verir. }\end{array}$ & - & - & - & - & 42 & 100,0 \\
\hline 22.Biyolojik çeşitliliğin önemini açıklar. & - & - & 18 & 42,9 & 24 & 57,1 \\
\hline $\begin{array}{l}\text { 23.Türkiye"nin biyolojik çeşitlilik açısından zengin } \\
\text { olmasının nedenlerini irdeler. }\end{array}$ & - & - & - & - & 42 & 100,0 \\
\hline $\begin{array}{l}\text { 24.Türkiye"deki biyolojik çeşitliliğin ve endemik } \\
\text { türlerin korunmasına yönelik bireysel ve iş birliğine } \\
\text { dayalı öneriler geliştirir. }\end{array}$ & - & - & - & - & 42 & 100,0 \\
\hline $\begin{array}{l}\text { 25.Güncel çevre sorunlarının sebeplerini ve olası } \\
\text { sonuçlarını örneklerle açıklar. }\end{array}$ & - & - & 13 & 31,0 & 29 & 69,0 \\
\hline $\begin{array}{l}\text { 26.Birey olarak güncel çevre sorunlarının ortaya } \\
\text { çıkmasındaki rolünü sorgular. }\end{array}$ & - & - & 15 & 35,7 & 27 & 64,3 \\
\hline $\begin{array}{l}\text { 27.Güncel çevre sorunlarının insan sağlığ1 üzerindeki } \\
\text { etkilerini örneklerle ortaya koyar. }\end{array}$ & 6 & 14,3 & 6 & 14,3 & 30 & 71,4 \\
\hline $\begin{array}{l}\text { 28.Güncel çevre sorunlarının çözümüne ilişkin öneriler } \\
\text { sunar. }\end{array}$ & - & - & 13 & 31,0 & 29 & 69,0 \\
\hline $\begin{array}{l}\text { 29.Çevre sorunlarının çözümüne yönelik çalışmalara } \\
\text { aktif olarak katılır. }\end{array}$ & - & - & 9 & 21,4 & 33 & 78,6 \\
\hline $\begin{array}{l}\text { 30.Atatürk"ün doğa ve çevre ile ilgili çalışma, görüş, } \\
\text { düşünce ve anılarından örnekler verir. }\end{array}$ & - & - & - & - & 42 & 100,0 \\
\hline
\end{tabular}

Tablo 2 incelendiğinde; 2. kazanıma "Uygun Değil" cevabını veren hiçbir uzmanın olmadığı görülmektedir. Uzmanlardan \%28,6's1 “Uygun” yönünde görüş belirtirken, \%71,4'ü "Kısmen Uygun” yönünde görüş belirtmişlerdir. Bu sonuç da "Kısmen Uygun” yönünde görüş belirtenlerin, "Uygun" yönünde görüş belirtenlere göre daha fazla olduğunu göstermektedir.

14., 16., 17. ve 27. kazanımlarda her üç seçeneği de işaretlenmiştir. Yüzde dağılımlarına bakıldığında, uzmanların görüşlerinin 14. kazanımda da "Uygun" \%33,4, "Kısmen Uygun” \%47,6, "Uygun Değil” ise \%19 olduğu sonucuna ulaşılmaktadır. Bu maddede, uzmanların yaklaşık yarısı "Kısmen Uygun" yönünde görüş belirtmişlerdir. 16. maddede uzmanların yarısına yakının yani \%45,2'sinin “Uygun”, 17. ve 27. maddelerde ise uzmanların büyük çoğunluğunun \%76,2 ve \%71,4’lık dağllım ile “Uygun Değill” görüşünde olduğu görülmektedir.

11., 21., 23., 24. ve 30. kazanımlara videoyu izleyen tüm uzmanlar "Uygun Değil” yanıtını vermişlerdir. 42 uzman grubunun tümünün yani \%100’ünün ayn1 görüşte olduğu görülmektedir. Uzmanlar, diğer kazanımlarda ise "Kısmen Uygun" ve "Uygun Değil” yönünde görüş belirtmektedir. Bu kazanımlardan, 1., 6., 8., 9., 10. ve 22. kazanımlarda katılımcıların dağılımları birbirine yakındır. Örneğin; 8. Kazanımda uzmanların \%47,6's1 “Kısmen Uygun”, \%52,4’ü “Uygun Değil” yönünde görüş belirtmişlerdir. Diğer kazanımlarda ise uzmanların çoğunun "Uygun Değil" yönünde görüş belirttiği sonucuna 
ulaşılmaktadır. Özellikle, uzmanların 5., 7. ve 20. kazanımlarda çoğunlukla "Uygun Değil” görüşünde oldukları belirlenmiştir.

Ayrıca aşağıda uzmanların “Gerçek Hayatta Ne İşimize Yarayacak?” adlı eğitim programının MEB 9. sınıf biyoloji dersi öğretim programı kazanımlarına uygun olup-olmadığı yönünde belirttikleri genel görüşleri verilmektedir.

"Canlılarn yapism olusturan inorganik ve organik bileşiklerin yapu ve görevlerini belirtir" kazanim ile ilgili olarak programda keratin, çinko ve iyottan yeterli düzeyde bahsetmis ve kazanımlar karşılamaya uygundur.

Kalsiyumun kemik ve dişler üzerindeki gelişiminden güzel ve ayrntıl bahsedilmis. Ancak. sadece kemik ve diş gelişimim üzerinde durulmus. Kalsiyumun bunlarm dişında vücutta gerçekleştirdiği çok önemli başka görevleri de var. Bunlardan biç bahsedilmemis.

Selüloz ve proteinlerin görevlerini çok güzel açklamıs ancak bu bileşiklerin yapısından babsedilmemis.

"Bakteria aleminin genel özelliklerini belirterek örnekler verir" kazanm ile ilgili olarak bakterilerin öneminden ve günlük hayatta isimize yarayan örneklerini çok güzel ve ayrntıl bir sekilde açılamıs ancak bakterilerin yapısindan ve genel özelliklerinden hic bahsetmemiş.” (U8)

"Bir bücre üzerinden canlularn ortak özelliklerini açılar" kazanıma dair bir bilgi verilmemis.

Canlilarn yapisin olusturan inorganik ve organik bileşiklerin yapı ve görevlerini belirtir" kazanımına Ca, Iyot, Cinko ve Protein anlatımında yer verilmis.

Yakın çevresindeki gözlemlerinden yararlanarak canlularn çesitliliğini fark eder, kazanım ile ilgili olarak günlük yaşamda bakterilerin kullanuldiğ alanlar ögretiyor.

Canhlar bilimsel sınflandırmanın önemini açklar" kazanım ile ilgili olarak canhlardan sadece bakteriler seçilmis.

Canllarn; Bakteria, Arkea, Protista, Bitkiler, Mantarlar ve Hayvanlar olarak 6 âlem altında sımıflandırldı̆̆ın belirtir" kazanımına yönelik ögrenciler sadece bakteriler simıfin ögrenebilir.

Bakteria âleminin genel özelliklerini belirterek örnekler verir" kazanmmna yönelik farkli meslek gruplarmm bakterilerin anlatması ilgi çekici olmus.

Biyolojik çeşitliliğin önemini açıklar" kazanım ile ilgili olarak bu kazanım bakterilerle sinırl kalir.

Güncel çevre sorunlarmın çözümüne iliskin öneriler sunar ve Cevre sorunlarmın çözümüne yönelike çalısmalara aktif olarak katılır" kazanımlarma alglerin anlatımında kusaca değinilmiş. "'(U10)

"Canlilarn yapısın olusturan inorganik ve organik bileşiklerin yapı ve görevlerini belirtir" kazanımına yönelik keratin zaten çok üzerinde durduğumuz bir organik bileşik değil. Bu yüzden verilen bilgi yeterli. Tabi sadece keratin için diğer bileşiklerden zaten bahsedilmemis. 8. bölümde anlatılan selüloz buramin konusu. Yapisindan bahsetmede eksiklikleri var ama çok değil. Uyguna da yakın. 9. bölümde anlatılan kalsiyumda buranm konusu. 11. bölümde anlatılan çinko iyot ve protein de buranın konusu. Protein görevleri anlatma bakımından yeterli olsa da yapısım açı.lama bakımından eksik. "Bakteria âleminin genel özelliklerini belirterek örnekler verir" kazanımma yönelik bakterilerin günlük hayatta işimize yarayan örneklerini açklamada yeterli ama genel özelliklerini alem olarak belirtmede yetersiz:" (U21) 
Tablo 3. Uzman Görüşlerine Göre TRT’de Yayınlanan “Gerçek Hayatta Ne İşimize Yarayacak?” Programının MEB Ortaöğretim 10. Sınıf Biyoloji Dersi Öğretim Programı Kazanımlarına Uygunluğuna İlişkin Bulgular

\begin{tabular}{|c|c|c|c|c|c|c|}
\hline \multirow{3}{*}{ 10. Sinıf Kazanımları } & \multicolumn{6}{|c|}{ K1smen } \\
\hline & \multicolumn{2}{|c|}{ Uygun } & \multicolumn{2}{|c|}{ Uygun } & \multicolumn{2}{|c|}{ Uygun Değil } \\
\hline & f & $\%$ & f & $\%$ & f & $\%$ \\
\hline $\begin{array}{l}\text { 1.Oksijenli solunumda glikoliz, Krebs döngüsü ve ETS } \\
\text { evrelerini şema üzerinde açıklar. }\end{array}$ & - & - & - & - & 42 & 100,0 \\
\hline $\begin{array}{l}\text { 2.Karbonhidrat, yağ ve proteinlerin hangi basamaklardan } \\
\text { oksijenli solunuma katıldığını şema üzerinde gösterir. }\end{array}$ & - & - & - & - & 42 & 100,0 \\
\hline $\begin{array}{l}\text { 3.Oksijensiz solunumda glikozdan etil alkol ve laktik asit } \\
\text { oluşumunu açıklar. }\end{array}$ & - & - & 8 & 19,0 & 34 & 81,0 \\
\hline 4.Oksijenli solunum ile oksijensiz solunumu karşılaştırır. & - & - & - & - & 42 & 100,0 \\
\hline 5.Kloroplastın yapısını ve fotosentez için önemini açıklar. & 12 & 28,6 & 30 & 71,4 & - & - \\
\hline $\begin{array}{l}\text { 6.Fotosentezde 1şığa bağımlı ve 1şıktan bağımsız olarak } \\
\text { gerçekleşen reaksiyonları ürün ve süreç açısından } \\
\text { karşılaştırır. }\end{array}$ & 4 & 9,5 & 12 & 28,6 & 26 & 61,9 \\
\hline 7.Fotosentez hızını etkileyen faktörleri belirtir. & - & - & 16 & 38,1 & 26 & 61,9 \\
\hline 8.Kemosentez yapan canlllara örnekler verir. & 2 & 4,8 & 10 & 23,8 & 30 & 71,4 \\
\hline $\begin{array}{l}\text { 9.Enerji dönüşümlerinde fotosentez ve solunumun ilişkisini } \\
\text { açıklar. }\end{array}$ & 10 & 23,8 & 20 & 47,6 & 12 & 28,6 \\
\hline 10.Mitozun evrelerini şema üzerinde açıklar. & - & - & - & - & 42 & 100,0 \\
\hline 11.Bitki ve hayvan hücrelerinde mitozu karşılaştırır. & - & - & - & - & 42 & 100,0 \\
\hline $\begin{array}{l}\text { 12.Tek hücreli ve çok hücreli canlılar için mitozun önemini } \\
\text { açıklar. }\end{array}$ & - & - & - & - & 42 & 100,0 \\
\hline 13.Eşeysiz üreme çeşitlerini örneklerle açıklar. & - & - & - & - & 42 & 100,0 \\
\hline 14.Mayozun evrelerini şema üzerinde açıklar. & - & - & - & - & 42 & 100,0 \\
\hline 15.Eşeyli üreme için mayozun önemini açılar. & - & - & - & - & 42 & 100,0 \\
\hline 16.Oogenez ve spermatogenezi şekil üzerinde açıklar. & - & - & - & - & 42 & 100,0 \\
\hline 17.Döllenmede gerçekleşen olayları açılar. & - & - & - & - & 42 & 100,0 \\
\hline 18.Partenogenezi örneklerle açılar. & - & - & - & - & 42 & 100,0 \\
\hline $\begin{array}{l}\text { 19.Popülasyon, komünite ve ekosistem arasındaki ilişkiyi } \\
\text { örneklerle açıklar. }\end{array}$ & - & - & 3 & 7,1 & 39 & 92,9 \\
\hline $\begin{array}{l}\text { 20.Ekosistemlerde abiyotik ve biyotik faktörleri sıralayarak } \\
\text { bunların karşılıklı etkilerini tartışır. }\end{array}$ & - & - & 4 & 9,5 & 38 & 90,5 \\
\hline $\begin{array}{l}\text { 21.Madde ve enerji akışında üretici, tüketici ve } \\
\text { ayrıştırıcıların rolünü örneklendirir. }\end{array}$ & 4 & 9,5 & 28 & 66,7 & 10 & 23,8 \\
\hline $\begin{array}{l}\text { 22.Ekosistemdeki besin zinciri, besin ağ1 ve besin piramidi } \\
\text { arasındaki ilişkiyi yorumlar. }\end{array}$ & 4 & 9,5 & 12 & 28,6 & 26 & 61,9 \\
\hline $\begin{array}{l}\text { 23.Enerji piramidi üzerinde ekosistemdeki enerji akışını } \\
\text { irdeler. }\end{array}$ & - & - & 9 & 21,4 & 33 & 78,6 \\
\hline $\begin{array}{l}\text { 24.Doğadaki madde döngülerini şekil üzerinde göstererek } \\
\text { önemini açıklar. }\end{array}$ & - & - & 8 & 19,1 & 34 & 80,9 \\
\hline
\end{tabular}

Tablo 3 incelendiğinde, araştırmaya katılan uzmanların tümü, 24 kazanımdan oluşan ölçeğin 12 kazanımına "Uygun Değil” yönünde görüş belirtmiştir. Bu durumdan, "Gerçek Hayatta Ne İşimize 
Yarayacak?” adlı televizyon programının ölçekteki 10. Sınıf kazanımlarının \%50'sini kazandırmakta yeterli olmadığ1 sonucu çıkmaktadır. 1., 2., 4., 10., 11., 12., 13., 14., 15., 16., 17. ve 18. kazanımlarla ilgili uzmanların \%100'ü “Uygun Değil” yönünde görüş belirmiştir.

3., 7., 19., 20., 23. ve 24. kazanımlara "Kısmen Uygun" ve "Uygun Değil" cevapları verilmiş "Uygun" yönünde hiçbir uzman görüş belirtmemiştir. Bu kazanımlarda, uzmanlar çoğu, "Uygun Değil” yönünde görüş belirtmişlerdir. Özellikle 19. ve 20. kazanımlarda "Kısmen Uygun” görüşünde olanların \%7,1 ve \%9,5’i olduğu belirlenmiş, "Uygun Değil" yönünde görüş belirtenlerin ise çok daha büyük bir oran ile uzmanların \%92,9 ve \%90,5’ini oluşturdukları sonucuna ulaşılmıştır.

Ölçekte her üç yönde görüş bildirilen kazanımların olduğu da belirlenmiştir. Bu kazanımlar, 6., 8., 9., 21. ve 22. Maddelerde yer almaktadır. 9. ve 21. kazanımlarda uzmanlar çoğunlukla "Kısmen Uygun" yönünde görüş belirtmişlerdir. 9. Kazanımda da uzmanların \%23,8’i “ Uygun”, \%47,6's1 "Kısmen Uygun”, \%28,6’s1 "Uygun Değill” yönünde görüş belirtmiştir. 6., 8. ve 22. kazanımlarda ise "Uygun Değill” yönünde görüş belirtenler daha fazladır. 8. kazanıma baktığımızda uzmanların \%4,8’i “ Uygun”, \%23,8’i "Kısmen Uygun”, \%71,4’ü “Uygun Değil” yönünde görüş bildirmiştir.

Uzmanların, 5. kazanımda ise “ Uygun” ve "Kısmen Uygun” yönünde görüş belirttikleri, uzmanların büyük bir çoğunluğunun yani \% 71,4’ünün “Kısmen Uygun” dediği belirlenmiştir.

Ayrıca aşağıda uzmanların "Gerçek Hayatta Ne İşimize Yarayacak?” adlı eğitim programının MEB 10. sınıf biyoloji dersi öğretim programı kazanımlarına uygun olup-olmadığ1 yönünde belirttikleri genel görüşleri verilmektedir.

"Kloroplastm yapısmm ve fotosentez için önemini açılar, kazanmmna yönelik fotosentezde kloroplastın öneminden söz edilmis, ancak yapısına değinilmemiş.” (U3)

Kloroplastın yapısım ve fotosentez için önemini açıklar, kazanımına yönelik fotosentez̧in canlllk için öneminden çok güzel bahsedilmis ancak keloroplastin yapısınin nasıl olduğundan ve kessımlarndan biç bahsedilmemis bu nedenle kismen uygun.

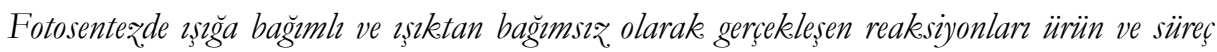
açsindan karşılasturr" kazanmm ile ilgili olarak reaksiyonlarn nasıl gerçekleștig̈inden bic bahsedilmemis."(U8)

"Karbonbidrat, yağ ve proteinlerin hangi basamaklardan oksijenli solunuma katuldiğm șema üzerinde gösterir, kazanımına yönelike proteinlerin vücuttaki işlevi anlatılmıs ama solunumla iliskilendirilmemistir.

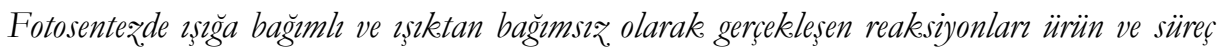

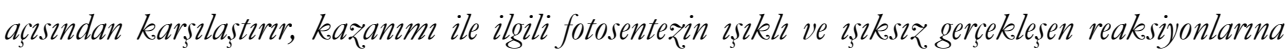
ayr ayn değinilmemişstir.

Kemosentez. yapan canllara ömekler verir, kazammina yönelik bakteriler ve mikroorganizmalar konusunda değinilmiștir.

Madde ve enerji akıısında üretici, tüketici ve ayrnștmolarn rolünü örneklendirir, kazanmo ile ilgili fotosentez konusu anlatulikeen besin zincirine değinilmiş fakat örneklerle belirtilmemiștir." (U13)

"Kloroplastın yapısım ve fotosentez için önemini açılalar, kazanmm ile ilgili fotosentez bölümünde kloroplastm yapısı detayli anlatılmamıs ama fotosentez çok etkili verilmiş.

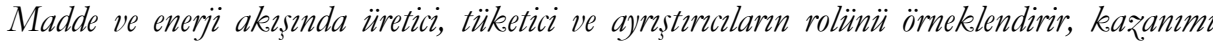
fotosentez, bölümünde anlatlmış. Mikroorganizmalar videosundan ayrışturcular olarak bakterilerden 


\begin{abstract}
bahsedilmiş. Protein videosunda kismen fotosentezden bahsedilmiştir. Fotosentez sonucu oluşan ürünlerden azot elde edilisi, bunun hayvanlara geçisi ve protein sentezi anlatılmıstır.

Ekosistemdeki besin zinciri, besin ăg ve besin piramidi arasindaki iliskiyi yorumlar. kazanım fotosentez bölümünde detaylı olmamakla birlik.te anlatılmıs.

Doğadaki madde döngülerini şekil üzerinde göstererek önemini açılar, kazanımı bakteriler videosunda C ve $N$ döngülerinden babsediyor ama sekil ya da görsel yok.tu."

Tablo 4. Uzman Görüşlerine Göre TRT’de Yayınlanan “Gerçek Hayatta Ne İşimize Yarayacak?” Programının MEB Ortaöğretim 11. Sınıf Biyoloji Dersi Öğretim Programı Kazanımlarına Uygunluğuna İlişkin Bulgular

\begin{tabular}{|c|c|c|c|c|c|c|}
\hline \multirow{3}{*}{ 11. Sınıf Kazanımları } & \multicolumn{6}{|c|}{ Kismen } \\
\hline & \multicolumn{2}{|c|}{ Uygun } & \multicolumn{2}{|c|}{ Uygun } & \multicolumn{2}{|c|}{ Uygun Değil } \\
\hline & f & $\%$ & $\mathrm{f}$ & $\%$ & f & $\%$ \\
\hline 1. Bitkisel dokuları örneklerle açılar. & - & - & 2 & 4,8 & 40 & 95,2 \\
\hline 2. Kök, gövde ve yaprağın yapı ve görevlerini açıklar. & - & - & 11 & 26,2 & 31 & 73,8 \\
\hline 3.Kök, gövde ve yaprak tiplerine örnekler verir & - & - & - & - & 42 & 100,0 \\
\hline $\begin{array}{l}\text { 4.Bitkilerde suyun topraktan alınması ve gövdede taşınmasını } \\
\text { sağlayan mekanizmaları açıklar. }\end{array}$ & - & - & 2 & 4,8 & 40 & 95,2 \\
\hline $\begin{array}{l}\text { 5.Bitkilerde fotosentez ürünlerinin taşınmasının nasıl } \\
\text { gerçekleştiğini açıklar. }\end{array}$ & - & - & 10 & 23,8 & 32 & 76,2 \\
\hline 6.Bitkinin beslenebilmesi için gerekli faktörleri açılar. & 2 & 4,8 & 13 & 30,9 & 27 & 64,3 \\
\hline 7.Bitkilerde besin tuzlarının önemini açıklar. & - & - & 15 & 35,7 & 27 & 64,3 \\
\hline 8.Bitki büyümesinde hormonların etkisini açılar. & - & - & - & - & 42 & 100,0 \\
\hline $\begin{array}{l}\text { 9.Fotoperiyodizm, nasti ve tropizma hareketlerini örneklerle } \\
\text { açılklar. }\end{array}$ & - & - & - & - & 42 & 100,0 \\
\hline $\begin{array}{l}\text { 10. Çiçeğin kısımlarının yapı ve görevlerini tam çiçek şekli } \\
\text { üzerinde belirtir. }\end{array}$ & - & - & - & - & 42 & 100,0 \\
\hline 11.Bir çiçek şekli üzerinde tozlaşmayı açıklar & - & - & - & - & 42 & 100,0 \\
\hline 12.Tohumlu bitkilerde döllenmeyi açıklar. & - & - & - & - & 42 & 100,0 \\
\hline 13.Bitkilerde tohumun yap1 ve önemini belirtir. & - & - & - & - & 42 & 100,0 \\
\hline 14.Bitkilerde görülen meyve tiplerini açıklar. & - & - & - & - & 42 & 100,0 \\
\hline 15.Tohumun taşınma yollarını örneklerle açıklar. & - & - & - & - & 42 & 100,0 \\
\hline 16.Çimlenmiş bir tohum şekli üzerinde kısımlarını gösterir. & - & - & - & - & 42 & 100,0 \\
\hline 17.Tohumun çimlenmesine etki eden çevresel faktörleri açılar. & - & - & - & - & 42 & 100,0 \\
\hline 18.Mendel ilkelerini örneklerle açıklar. & - & - & - & - & 42 & 100,0 \\
\hline $\begin{array}{l}\text { 19.Monohibrit ve dihibrit çaprazlamaların olası sonuçlarını } \\
\text { Punnett Karesini kullanarak çözer. }\end{array}$ & - & - & 4 & 9,5 & 38 & 90,5 \\
\hline $\begin{array}{l}\text { 20.Kontrol çaprazlamasının önemini örnekler üzerinden } \\
\text { irdeler. }\end{array}$ & - & - & 2 & 4,8 & 40 & 95,2 \\
\hline $\begin{array}{l}\text { 21.Eksik baskınlık, eş baskınlık ve çok alelliği örneklerle } \\
\text { açılklar. }\end{array}$ & - & - & 4 & 9,5 & 38 & 90,5 \\
\hline 22.Eşeye bağlı kalıtımı örneklerle açıklar. & - & - & 21 & 50,0 & 21 & 50,0 \\
\hline 23.Kromozomların yapı ve sayısındaki değişimleri açıklar. & - & - & 20 & 47,6 & 22 & 52,4 \\
\hline
\end{tabular}




\begin{tabular}{|c|c|c|c|c|c|c|}
\hline 24.DNA"nın yapısını şekil ya da model üzerinde açılar. & 20 & 47,6 & 22 & 52,4 & - & - \\
\hline 25.DNA"nın kendini eşlemesini ve önemini açıklar. & 11 & 26,2 & 29 & 69,0 & 2 & 4,8 \\
\hline 26.RNA"nın yapısı ve çeşitlerini açıklar. & 2 & 4,8 & 15 & 35,7 & 25 & 59,5 \\
\hline 27.Protein sentezini açıklar. & - & - & 12 & 28,6 & 30 & 71,2 \\
\hline $\begin{array}{l}\text { 28.Hayvan ve bitki üretiminde kullanılan sslah yöntemlerine } \\
\text { örnekler verir. }\end{array}$ & 15 & 35,7 & 6 & 14,3 & 21 & 50,0 \\
\hline $\begin{array}{l}\text { 29.Gen mühendisliği ve biyoteknoloji uygulamalarına örnekler } \\
\text { verir. }\end{array}$ & 30 & 71,7 & 12 & 28,6 & - & - \\
\hline $\begin{array}{l}\text { 30.Atatürk"ün bilim ve teknolojiye verdiği önemi biyoloji } \\
\text { bilimi açısından değerlendirir. }\end{array}$ & - & - & - & - & 42 & 100,0 \\
\hline $\begin{array}{l}\text { 31.Komünitenin yapısını ve buna etki eden faktörleri } \\
\text { örneklerle açıklar. }\end{array}$ & - & - & - & - & 42 & 100,0 \\
\hline $\begin{array}{l}\text { 32.Komünitede tür içi ve türler arasındaki rekabeti örneklerle } \\
\text { açıklar. }\end{array}$ & - & - & - & - & 42 & 100,0 \\
\hline $\begin{array}{l}\text { 33.Komünitede türler arasında simbiyotik ilişkileri örneklerle } \\
\text { açıklar. }\end{array}$ & - & - & 2 & 4,8 & 40 & 95,2 \\
\hline 34.Popülasyon dinamiği ve taşıma kapasitesini açıklar. & - & - & - & - & 42 & 100,0 \\
\hline $\begin{array}{l}\text { 35.Bazı canlı türlerinin neslinin tehlikede olmasını nedenleriyle } \\
\text { ortaya koyar. }\end{array}$ & - & - & - & - & 42 & 100,0 \\
\hline 36.Biyom ve ekosistem arasındaki ilişkiyi açıklar. & - & - & 6 & 14,3 & 36 & 85,7 \\
\hline 37.Dünyadaki başlica karasal & - & - & 14 & 33,3 & 28 & 66,7 \\
\hline
\end{tabular}

Tablo 4. incelendiğinde, araştırmaya katılan uzmanların tümü, 37 kazanımdan oluşan ölçekte 17 kazanıma "Uygun Değil” yönünde görüş belirtmiştir. Bu durumdan, televizyon programının ölçekteki kazanımların yarısına yakınını yani \%45,9’unu sağlamadığı sonucunu ifade etmektedir. 3., 8., 9., 10., 11. 12., 13., 14., 15., 16., 17., 18., 30., 31., 32., 34. ve 35. kazanımlarda \%100 olarak "Uygun Değil” yönünde görüş belirtilmiştir.

"Kısmen Uygun” ve "Uygun Değil”" seçeneklerinin işaretlendiği kazanımların çoğunlukta olduğu görülmektedir. 1., 2., 4., 5., 7., 19., 20., 21., 22., 23., 27., 33., 36. ve 37. kazanımlar olmak üzere 14 kazanımda da "Kısmen Uygun” ve “Uygun Değil” yönünde görüş belirtilmiştir. Bu kazanımlar incelendiğinde, 1., 4., 20. ve 33. kazanımlarda uzmanların \%4,8’inin “Kısmen Uygun”, \%95,2ésinin “Uygun Değil” görüşünde olduğu görülmektedir. Bu sonuçlar, uzmanların çoğunun, TV programının bu kazanımları sağlayamadığ1 görüşünde olduğunu göstermektedir. "Kısmen Uygun” ve "Uygun Değil”" seçeneklerinin işaretlendiği diğer kazanımlarda da "Uygun Değil" yönünde uzmanların daha çok görüş belirttikleri görülmektedir.

Araştırmaya katılan uzmanların her üç seçeneğe yönelik görüşte olduğu 6., 25., 26. ve 28. kazanımlar bulunmaktadır. 6. ve 26. kazanımlarda uzmanlar, "Uygun Değil” yönünde görüş belirtmişlerdir. Sırası ile uzmanların \%64,3 ve \%59,5’i bu yönde görüş belirtmiştir. 28. kazanımda da, "Uygun” yönünde görüş belirten uzmanların \%35,7'sini, “Uygun Değil” görüşünde olanların ise \%50'sini oluşturduğu görülmektedir.

24. ve 25. kazanımlarda uzmanların "Uygun Değil” yönünde görüş belirtmediği görülmüştür. 24. Kazanım incelendiğinde "Uygun” ve “Kısmen Uygun” cevabını verenlerin sıras1 ile \%47,6 ve \%52,4 
oranlarında olduğu sonucuna ulaşılmaktadır. Bu sonuçla, iki farklı değerlendirmede bulunan uzmanların sayısının birbirine yakın olduğu belirlenmiştir. 29. kazanımda ise "Uygun" yönünde görüş belirten uzmanların çoğunlukta olduğu saptanmıştır. Araştırmaya katılanların \%71,7’sinin “ uygun”, \%28,6'sının ise "Kısmen Uygun” görüşünde olduğu sonucuna ulaşılmıştır.

Ayrıca aşağıda uzmanların "Gerçek Hayatta Ne İşimize Yarayacak?” adlı eğitim programının MEB 11. sınıf biyoloji dersi öğretim programı kazanımlarına uygun olup-olmadığı yönünde belirttikleri genel görüşleri verilmektedir.

“Hayvan ve bitki üretiminde kullanlan ıslah yöntemlerine örnekler verir, kazanmmna yönelik. sadece verimli döl elde edilmede kullamuldiğg, ifade edilmektedir. Ülkemizde ki gen bankalarnndan ve endemik türlerin korunmasindan babsedilmemektedir.

Gen mühendisligi ve biyoteknoloji uygulamalarna örnekler verir, kazanmm ile ilgili olarake daha çok adli top uygulamalarna yer verilmis olmasina rağmen, hayvan ve bitki üretiminde uslah yöntemlerinden, gen transferlerinden, GDO yygulamalarndan, olast etkilerinden babsedilmemektedir. Örneğin gen transferleri ile insülin gibi hormonlarn üretimi ve şeker hastalan için önemi üzerinde durulmamaktadrr. Insan genom projesinden babsedilmesi, farmagogenetik. tip, genetik tan, GDO çalısmalarndan babsedilmesi güzel. Bir önceki programm eksikliklerini tamamlar nitelikte olmuş. Öğrencilerin bu çalsşmalardan haberdar olmasi gerekir. Mikroorganizmalarn kullanımına yönelik örnekler diger bölümlerin eksiklerini tamamlar nitelikte olmus." (U2)

"Bitkilerde besin tuحlarmm önemini açklar" kazanmmana iyottan babsederken çok kisa değinilmiş. Orada buna daha çok yer verilebilirdi." (U7)

"DNA'nın yapısm șekil ya da model üzerinde açılar" kazanmmna yönelik DNA'nn yapımıyla ilgili coke kessa bir açlelama vard, o nedenle kesmen işaretlendi.

'DNA'nın yapısın şekil ya da model üzerinde açılar, kazammı ile ilgili olarak DNA'nn şeklinden yeterince bahsedilmemis. Sadece temel yapr taşınn nükleotitler olduğg söylenmis. Ancak bunlarn birbirine nasıl bağlandiğ ve yapısında bulunana diğer moleküller açıklanmamıs.

DNA"nnn kendini eşlemesini ve önemi açklar, kazanmmna yönelik. DNA'nn bangi durumlarda ve nasil eşlendiginden ve öneminden hiç babsetmemis.

RNA'nn yapısı ve gessitlerini aģılar, kazanmm ile ilgili RNA'nun sadece bir nükleike asit çeşidi olduğundan babsetmis. Onun dışında yapısı ve çessitleri üzerinde biç durulmamış.

Protein sentezini açılar, kazanmmna yönelik protein sentezi olayn ve nasıl gerçeklesstiğinden bic bahsedilmemis.

Gen mühendisliği ve biyoteknoloji uygulamalarna örnekler verir, kazanmmna yönelik bu konu cok ayrntil ve kazanmmlara uygun bir șekilde anlatılmusttr." (U8)

"Kök, gövde ve yaprağin yapı ve görevlerini açlklar, kazanımına yönelik. Yaprak ve fotosentę. iliskilendirilmis.

Bitkilerde fotosentez ürünlerinin taşınmasmm nasil gerçeklesstig̈ini açılelar, kaz̧ammo ile ilgili fotosentez konusunda ürünlerin tașinmasindan bahsedilmemiș.

Bitkilerde besin tuશlarmm önemini ą̧ılar, kazanmmna iyottan bahsederken değinilmiş.

Hayvan ve bitki üretiminde kullanulan uslah yöntemlerine örnekler verir, kazanmmndan biyoteknoloji anlaturken babsedilmişs. Gen mühendisliği ve biyoteknoloji uygulamalarna örnekler verir, kazanmmna yönelik mikroorganizmalarm günlük hayatta nasul kullanuldiğndan bahsederken örnekler veriliyordu.

Dünyadaki başlca karasal ve sucul biyomlara ömekler verir" kazanmm ile ilgili suda ve karada yasayan canllardan örnekler mevcuttur." (U13) 
Tablo 5. Uzman Görüşlerine Göre TRT’de Yayınlanan “Gerçek Hayatta Ne İşimize Yarayacak?” Programının MEB Ortaöğretim 12. Sınıf Biyoloji Dersi Öğretim Programı Kazanımlarına Uygunluğuna İlişkin Bulgular

\begin{tabular}{|c|c|c|c|c|c|c|}
\hline \multirow[t]{2}{*}{ 12. Sinıf Kazanımları } & \multicolumn{2}{|c|}{ Uygun } & \multicolumn{2}{|c|}{$\begin{array}{l}\text { Kismen } \\
\text { Uygun }\end{array}$} & \multicolumn{2}{|c|}{ Uygun Değil } \\
\hline & f & $\%$ & $\mathbf{f}$ & $\%$ & f & $\%$ \\
\hline $\begin{array}{l}\text { 1.Sindirimin özelleşmiş kısımlar içerisinde } \\
\text { gerçekleştiğini örneklerle belirtir. }\end{array}$ & - & - & 12 & 28,6 & 30 & 71,4 \\
\hline $\begin{array}{l}\text { 2.İnsanda besinlerin sindirim kanalındaki hareketi, } \\
\text { parçalanması ve emilimini şekil/şema kullanarak } \\
\text { açıklar. }\end{array}$ & - & - & 2 & 4,8 & 40 & 95,2 \\
\hline $\begin{array}{l}\text { 3. Herbivor, karnivor ve omnivor hayvanlarda diş-çene } \\
\text { yapısı, mide yapısı ve bağırsak uzunluklarını karşılaştırır. }\end{array}$ & - & - & 11 & 26,2 & 31 & 73,8 \\
\hline $\begin{array}{l}\text { 4.Hayvanlarda deri, trake, solungaç ve akciğer } \\
\text { solunumunu karşılaştırır. }\end{array}$ & - & - & - & - & 42 & 100,0 \\
\hline 5.İnsanda akciğer solunumunu açıklar. & - & - & 2 & 4,8 & 40 & 95,2 \\
\hline $\begin{array}{l}\text { 6.Alveollerden dokulara, dokulardan alveollere gaz } \\
\text { taşınmasını açıklar. }\end{array}$ & - & - & 2 & 4,8 & 40 & 95,2 \\
\hline 7.Açık ve kapalı kan dolaşımını karşılaştırır. & - & - & - & - & 42 & 100,0 \\
\hline $\begin{array}{l}\text { 8.Balık, kurbağa ve memelilerdeki kan dolaşımını } \\
\text { karşılaştırır. }\end{array}$ & - & - & - & - & 42 & 100,0 \\
\hline $\begin{array}{l}\text { 9.İnsanda kalp, kan ve damarların yapı ve görevlerini } \\
\text { açıklar. }\end{array}$ & - & - & - & - & 42 & 100,0 \\
\hline 10.Lenf dolaşımının yapı ve görevlerini açıklar. & - & - & - & - & 42 & 100,0 \\
\hline $\begin{array}{l}\text { 11.Vücudun antijenlere karşı immuno biyolojik } \\
\text { cevabını örneklendirir. }\end{array}$ & 2 & 4,8 & 17 & 40,5 & 23 & 54,8 \\
\hline $\begin{array}{l}\text { 12.Bağışıklık sisteminin alerjenlere verdiği tepki ve } \\
\text { baskılandığı durumlara güncel örnekler verir. }\end{array}$ & 4 & 9,5 & 12 & 28,6 & 26 & 61,9 \\
\hline 13.Hayvanlarda boşaltımı örnekler üzerinden açıklar. & - & - & - & - & 42 & 100,0 \\
\hline $\begin{array}{l}\text { 14.İnsanda üriner sistemi oluşturan yap1 ve organlar ile } \\
\text { görevlerini şekil/şema üzerinde açılklar. }\end{array}$ & - & - & - & - & 42 & 100,0 \\
\hline $\begin{array}{l}\text { 15.Böbrek, deri ve akciğerin homeostatik işlevlerine } \\
\text { örnekler verir. }\end{array}$ & - & - & - & - & 42 & 100,0 \\
\hline 16.Boşaltımın homeostazi açısından önemini tartışır. & - & - & - & - & 42 & 100,0 \\
\hline 17.Farklı hayvanlarda destek ve hareketi karşılaştırır. & - & - & - & - & 42 & 100,0 \\
\hline $\begin{array}{l}\text { 18.İnsanda kemik ve eklem tiplerini şema/model } \\
\text { üzerinde göstererek görevlerini açıklar. }\end{array}$ & - & - & 13 & 30,9 & 29 & 69,1 \\
\hline $\begin{array}{l}\text { 19.İnsandaki kas çeşitlerini yap1 ve görev açısından } \\
\text { karşılaştırır. }\end{array}$ & - & - & 13 & 30,9 & 29 & 69,1 \\
\hline $\begin{array}{l}\text { 20.Hareket sırasında iskelet-kas iş birliğini antagonist } \\
\text { (zıt çalışan) kaslarla açıklar. }\end{array}$ & - & - & - & - & 42 & 100,0 \\
\hline $\begin{array}{l}\text { 21.Farklı hayvanlarda sinir sistemini örnekler ile } \\
\text { karşılaştırır. }\end{array}$ & - & - & - & - & 42 & 100,0 \\
\hline 22.Nöronun yap1 ve çeşitlerini açıklar. & - & - & - & - & 42 & 100,0 \\
\hline $\begin{array}{l}\text { 23.Uyartının nöronda oluşumu ve bir nörondan } \\
\text { diğerine aktarılmasını açıklar. }\end{array}$ & - & - & - & - & 42 & 100,0 \\
\hline $\begin{array}{l}\text { 24.İnsanda merkezî ve çevresel sinir sistemini } \\
\text { şekil/şema üzerinde göstererek görevlerini belirtir. }\end{array}$ & - & - & - & - & 42 & 100,0 \\
\hline 25.İnsanda refleks yayını şekil/şema üzerinde açıklar. & - & - & - & - & 42 & 100,0 \\
\hline $\begin{array}{l}\text { 26.İnsanın duyu organlarında uyarıların alınması, } \\
\text { uyartıların taşınması ve cevap verilmesini şekil üzerinde } \\
\text { açıklar. }\end{array}$ & - & - & 2 & 4,8 & 40 & 95,2 \\
\hline $\begin{array}{l}\text { 27.İnsandaki endokrin bezlerin ürettiği hormonların } \\
\text { görevlerini açıklar. }\end{array}$ & - & - & 22 & 52,4 & 20 & 47,6 \\
\hline
\end{tabular}




\begin{tabular}{|c|c|c|c|c|c|c|}
\hline 28.Hormonların çalışma mekanizmasını açıklar. & - & - & 22 & 52,4 & 20 & 47,6 \\
\hline $\begin{array}{l}\text { 29.Homeostazinin sağlanmasında denetleyici } \\
\text { düzenleyici sistemin rolünü örneklerle açıklar. }\end{array}$ & - & - & 10 & 23,8 & 32 & 76,2 \\
\hline 30.Hayvanlarda iç ve dış döllenmeye örnekler verir. & - & - & - & - & 42 & 100,0 \\
\hline $\begin{array}{l}\text { 31.İnsanda erkek ve dişi üreme organlarının görevlerini } \\
\text { belirtir. }\end{array}$ & - & - & - & - & 42 & 100,0 \\
\hline 32.İnsanda embriyonik gelişimi açıklar. & - & - & 17 & 40,5 & 25 & 59,5 \\
\hline $\begin{array}{l}\text { 33.Doğuştan gelen ve öğrenilen davranışları örneklerle } \\
\text { açıklar. }\end{array}$ & - & - & - & - & 42 & 100,0 \\
\hline 34.Sosyal davranışlara örnekler verir. & - & - & - & - & 42 & 100,0 \\
\hline $\begin{array}{l}\text { 35.Hayvanlarda yön bulma, yer belirleme gibi } \\
\text { davranışlara örnekler verir. }\end{array}$ & - & - & - & - & 42 & 100,0 \\
\hline $\begin{array}{l}\text { 36.Yaşamın ortaya çıkışı ile ilgili abiyogenez, biyogenez, } \\
\text { panspermia, ototrof, heterotrof, yaratılış vb. Hipotez ve } \\
\text { görüşleri özetler. }\end{array}$ & - & - & 31 & 73,8 & 11 & 26,2 \\
\hline $\begin{array}{l}\text { 37.Fosillerin yaşamın anlaşılmasına sağladığı katkılara } \\
\text { örnekler verir. }\end{array}$ & - & - & 2 & 4,8 & 40 & 95,2 \\
\hline $\begin{array}{l}\text { 38.Canlıların embriyolojik, biyokimyasal, anatomik ve } \\
\text { genetik yapılarındaki benzerlik ve farklılıkların evrimin } \\
\text { açıklanmasına katkılarına örnekler verir. }\end{array}$ & - & - & 4 & 9,5 & 38 & 90,5 \\
\hline 39.Evrime ilişkin görüşleri özetler. & - & - & 10 & 23,8 & 32 & 76,2 \\
\hline $\begin{array}{l}\text { 40.Doğada meydana gelebilecek iklimsel } \\
\text { değişikliklerden hareketle, zaman içinde evrim } \\
\text { sürecinin ve yaşamın nasıl etkilenebileceğini tartışır. }\end{array}$ & - & - & 8 & 19,1 & 34 & 80,9 \\
\hline $\begin{array}{l}\text { 41.Madde ve besin kaynaklarının yaşam için önemini } \\
\text { örneklerle açılar. }\end{array}$ & 17 & 40,5 & 20 & 47,6 & 5 & 11,9 \\
\hline $\begin{array}{l}\text { 42.Madde ve besin kaynaklarının sürdürülebilirliğinin } \\
\text { önemini tartışır. }\end{array}$ & 7 & 16,7 & 22 & 52,4 & 13 & 30,9 \\
\hline $\begin{array}{l}\text { 43.Karasal ve sucul biyolojik çeşitliliğin korunmasının } \\
\text { önemini fark eder. }\end{array}$ & 2 & 4,8 & 10 & 23,8 & 30 & 71,4 \\
\hline $\begin{array}{l}\text { 44.Biyolojik çeşitliliğin sürdürülebilirliğine yönelik } \\
\text { alınması gereken önlemleri belirtir. }\end{array}$ & 2 & 4,8 & 14 & 33,3 & 26 & 61,9 \\
\hline $\begin{array}{l}\text { 45.Tarım ve hayvancilıkta kullanılan yerel türlerin } \\
\text { korunmasının önemini irdeler. }\end{array}$ & 2 & 4,8 & 16 & 38,1 & 24 & 57,1 \\
\hline $\begin{array}{l}\text { 46.Bozulan bir çevrenin rehabilite edilme yollarını } \\
\text { tartışı. }\end{array}$ & 3 & 7,1 & 12 & 28,6 & 27 & 64,3 \\
\hline $\begin{array}{l}\text { 47.Çevre ile ilgili rehabilitasyon çalışmalarına gönüllü } \\
\text { olarak katılır. }\end{array}$ & - & - & 4 & 9,5 & 38 & 90,5 \\
\hline
\end{tabular}

Tablo 5 incelendiğinde, araştırmaya katılan uzmanların tümü 47 kazanımdan oluşan ölçeğin 21 kazanımına yönelik olarak "Uygun Değil” görüşündedir. Bu durumdan, televizyon programının ölçekteki kazanımların yarısına yakınının yani \%44,7'sinin uygun olmadığı sonucu çıkmaktadır. 4., 7., 8., 9., 10., 13. , 14., 15., 16., 17., 20., 21., 22., 23., 24., 25., 30., 31., 33., 34. ve 35. Kazanımlarla ilgili uzmanların hepsi “Uygun Değil” yönünde görüş belirtmişlerdir.

Diğger taraftan 1., 2., 3., 5., 6., 18., 19., 26., 27., 28., 29., 32., 36., 37., 38., 39., 40. ve 47. kazanımlarında “Kısmen Uygun” ve "Uygun Değil” yönünde görüş belirtilmiştir. 2., 5., 6., 26. ve 37. kazanımlara "Uygun Değil” yönünde görüş belirtenler, uzmanların \%95,2'sini, “Kısmen Uygun” görüşünde olanlar ise \%4,8'ini oluşturmaktadır. Uzman grubunda, TV programının bu kazanımlara uygun olmadığ1 yönünde görüş belirtenlerin çoğunlukta olduğu görülmektedir. "Uygun Değil” yönünde görüş belirtenlerin çoğunlukta 
olduğu 38. ve 47. kazanımların her ikisinde de uzmanların \%90,5’inin aynı görüşte olduğu belirlenmiştir. 27., 28. ve 32. kazanımlarda ise verilen cevapların oranlarının birbirine yakın olduğu görülmektedir. 27. ve 28. kazanımlarda uzmanların \%52,4'ünün “Kısmen Uygun”, \%47,6’sının ise "Uygun Değil” görüşünde olduğu sonucu çıkmaktadır. Sadece bir kazanımda "Kısmen Uygun” görüşünün "Uygun Değil” görüşüne göre daha fazla uzman tarafından tercih edildiği görülmüştür. 36. kazanımda da uzmanların \% \%73,8`i programın bu kazanıma "Kısmen Uygun" olduğunu ifade etmişlerdir.

Araştırmaya katılan uzmanlar, 11., 12., 41., 42., 43., 44., 45. ve 46. kazanımlarda her üç seçenek yönünde görüş belirtmiştir. 12., 43., 44., 45. ve 46. kazanımlara bakıldığında "Uygun Değill” yönünde daha çok kişinin görüş belirttiği, 41. ve 42. maddelerde ise "Kısmen Uygun" görüşünde olan uzmanların daha çok olduğu görülmektedir. Özellikle 41. kazanımda uzmanların \%40,5’inin "Uygun”, \%47,6’sının “Kısmen Uygun” yönünde görüş belirttiği görülmektedir.

Ayrıca aşağıda uzmanların "Gerçek Hayatta Ne İşimize Yarayacak?” adlı eğitim programının MEB 12. sınıf biyoloji dersi öğretim programı kazanımlarına uygun olup-olmadığ1 yönünde belirttikleri genel görüşleri verilmektedir.

"Insandaki kas çeşitlerini yapr ve görev açısından karşılaștırr, kazanum ile ilgili proteinlerden bahsederken kaslar ile ilgili çok kisa açılama var ancak yeterli değil.

Yaşamin ortay a çlkış ile ilgili abiyogenez, biyogenez, panspermia, ototrof, heterotrof, yaratulss vb. Hipotez ve görüsleri özetler, kazanmmna yönelik alglerden babsederken Dünya'nn olusumundaki oksijen kaynağgna (alglere) kisaca değinilmiş.

Madde ve besin kaynaklarmm yaşam için önemini örneklerle açılar, kazanmm ile ilgili olarak iyot, protein gibi konularda detayl olarak madde ve besin kaynaklarmm yaşam için önemine yer verilmisti.

Karasal ve sucul biyolojik çesiitliliğin korunmasinn önemini fark eder, kazanmmna yönelike alglerin biyodizelde kullamlmasindan bahsedilmis..” (U7)

"İnsanda kemik ve eklem tiplerini şema/model üzerinde göstererek görevlerini açılar, kazanmmina yönelik kalsiyumdan babsederken dişlerdeki kalsiyum birikmesinden babsedebilmis.

İnsandaki kas çessitlerini yapr ve görev açısından karşılaștırr, kazanımına proteinlerden babsederken kaslarda protein zenginlï̈i vurgulanmus.

Insandaki endokrin bęlerin ürettiüi hormonlarn görevlerini açlklar, kazanmmndan iyot anlathliken yetersizliğ̈nde tiroit kanseri olabileceği ve diğer tiroit hastallklarnndan bahsedilmişs.

Insanda embriyonik gelisimi açılar, kazanmmndan kalsiyum ibtiyacmm gebelerde fazla olmasindan babsedilmiş." (U11)

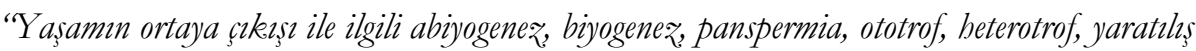
vb. Hipotez ve görïsleri özetler, kazammma alglerden bahsederken Dünya'non olusumundaki oksijen kaynağına (alglere) kisaca değinilmis.

Karasal ve sucul biyolojik çessitliliğ̈n korunmasmm önemini fark eder, kazanımindan alglerin biyodizelde kullanulmasindan babsedilmiş. (U17)

Insanlarn duyu organlarnda uyarlarn almmasi, uyartılarn taşmması ve cevap verilmesini şekil üzerinde ą̧ılar, kazanmmnda derinin yapısındaki keratinden bahsediyor." (U30)

\subsection{Uzman Görüşlerine Göre TRT’de Yayınlanan “Gerçek Hayatta Ne İşimize Yarayacak?”}

\section{Programının İçerik, Süre ve Konunun İşlenişine İlişkin Bulgular}

Araştırmaya katılan uzmanlar, hazırlanan ölçme aracıyla programın içeriğinin, süresinin ve konunun işlenişinin ortaöğretim biyoloji öğretim programına uygunluğu ile ilgili görüşlerini aktarmışlardır. 
Tablo 6. Uzman Görüşlerine Göre TRT’de Yayınlanan “Gerçek Hayatta Ne İşimize Yarayacak?” Programının İçerik, Süre ve Konunun İşlenişine İlişkin Bulgular

\begin{tabular}{ccccccc} 
& \multicolumn{2}{c}{ Uygun } & \multicolumn{2}{c}{ Kismen Uygun } & \multicolumn{2}{c}{ Uygun Değil } \\
\cline { 2 - 7 } & f & $\mathbf{0}$ & f & $\mathbf{0}$ & f & $\mathbf{\%}$ \\
\hline İçerik & 17 & 40,5 & 13 & 30,9 & 12 & 28,6 \\
\hline Süre & 30 & 71,4 & 12 & 28,6 & - & - \\
\hline Konunun İşlenişi & 20 & 47,6 & 14 & 33,3 & 8 & 19,1 \\
\hline
\end{tabular}

TRT Okul kanalında ekranlara gelen “Gerçek Hayatta Ne İşimize Yarayacak?” adlı eğitim içerikli televizyon programının içeriği ortaöğretim biyoloji dersi öğretim programına uygunluğunu tespit etmek amacı ile Tablo 6 incelendiğinde, araştırmaya katılan uzman grubunun "Uygun”, "Kısmen Uygun" ve "Uygun Değil” kriterlerinin hepsinde görüş bildirdikleri görülmektedir. Uzmanlannn \%40,5’i "Uygun", \%30,9’u “Kısmen Uygun” ve \%28,6’s1 “Uygun Değill” değerlendirmesinde bulunmuşlardır.

“Gerçek Hayatta Ne İşimize Yarayacak?” eğitim içerikli televizyon yayınında işlenen biyoloji konularına verilen sürenin değerlendirilmesinde uzmanlar olumsuz bir durum ifade etmemişlerdir. Tablo 6’da görüldüğü gibi, uzmanların \%71,4’ü gibi büyük bir çoğunluğunun "Uygun” seçeneğinde görüş belirttikleri belirlenmiştir. Uzmanların \%28,6'sının ise "Kısmen Uygun” görüşünde oldukları sonucuna ulaşılmaktadır.

Programda konular işlenirken izlenen yöntem ve tekniklerin müfredata uygunluğu açısından uzmanlar, "Uygun”, "Kısmen Uygun” ve "Uygun Değil” yönünde görüş belirtmişlerdir. Araştırmaya katılan uzmanların \%47,6’s1 “Uygun”, \%33,3’ü “Kısmen Uygun” ve \%19,1’i de "Uygun Değill” yönünde görüş belirtmişlerdir. Bu dağılımlardan yola çıkarak, uzmanların yaklaşık yarısının konunun işlenişinin müfredata uygun olduğu görüşünde oldukları, ancak konular işlenirken izlenen yöntem ve tekniklerin yetersiz olduğunu düşünenlerin de olduğu sonucuna ulaşılmaktadır.

Aşağıda TRT “de yayınlanan “Gerçek Hayatta Ne İşimize Yarayacak?” adlı eğitim programının içeriği hakkında uzmanların görüşlerinden örnekler yer almaktadır.

"Ëğitim programlarmın içerĭgi oluşturulurken ögretim programlarmm içeriğgi ve kazanımlarmm dikekate alınmadiğın düşünüyorum. Ayrıa bazı konular gereksiz detaylı olmus." (U2)

"Program adı ile uyusmaktadır. Ancak kazanımlar paralelinde değerlendirildiğinde yüzeysel gözükmektedir.” (U3)

"İcerikte biraz zayıf kalındiğın düsünüyorum. Sadece İlgi çekebileceği düsünülen konulara değinilmis. Programın ismi ve amac doğrultusunda, yani günlük hayatta ne işimize yarayacak başlı̆̆ına bağh kalınarak içerik kısa tutularak haz̦rlanmıs. Kazanımlar doğrultusunda içerik daba da zenginlestirilebilirdi diye düsünüyorum.” (U5)

"TRT'de yaymlanan eğitim programlarm yayın akuş içinde iz̨lemedim. Ancak analizini yaptı̆̆mı video bağlamında içeriğin kesinlikle faydal olduğunu düş̈̈nüyorum. Ancak yine incelediğimiz videonun biyoloji kazanmlar ile ilişkisi karşılaştırmasinda doğrudan ilişkili olabilecek çok az kazanım olduğunu gördüm nitekim içerik bu anlamda żenginleștirilebilir. Ancak içerikteki baz? hususlarm gerçekten ilgi çekici nitelikte olduğunu düsünüyorum.” (U7)

"TRT'de yayınlanan eğitim programlarmm içeriği günlük hayatta karşılaşabileceğimiz. konular üzerinedir. Bu da sadece ögrencilerin değil tüm bireylerin dikkatini çekmektedir.” (U11) 
"TRT'deki eğitim programlarm ižlemiyorum. Ancak verdiğiniz. "Gerçek hayatta ne işimiz̨e yarayacak?" programı örgün eğitimdeki biyoloji kazanımlarna uygun bir içerik.te değil. Zaten buna yönelik hazurlanmıs bir program da değil anladı̆̆ım kadarıla. Popüler manada ilgi çekmek. amacıyla hažrlanmış, kismi bilgiler vermektedir.” (U20)

"Program güzel hazırlanmıs ve yardımo bir kaynak. Ancak içerik eğitim programınn içeriğine tam anlamiyla uygunluk göstermemektedir.” (U25)

"Program içeriği iyi düsünülmüs ve gayet iyi haz̧ırlanmıs. Sorulan sorulara açıklayıcı cevaplar verilmis.s. Bilgilerin güncel hayata uygunluğu gösterilmis..” (U29)

"Ë̆gitim programlar içeriği kazanmlara kismen uygundur. Daha çok derse giris etkinliği olarak kullanmaya, ögrencilerde dikkeat çekme amaçı kullanmaya uygun.” (U33)

"Programın içeriği birebir uygun olmasa da baz̨ bölümlerde kısmen uygunluk bulunuyor." $(\mathrm{U} 40$

Aşağıda TRT’de yayınlanan “Gerçek Hayatta Ne İşimize Yarayacak?” adlı eğitim programının süresi hakkında uzmanların görüşlerinden örnekler yer almaktadır.

"Süre iyi ama biraz daba uzun olabilir. Daha fazla örneklemeler olabilir. Konulara daha fazla zaman ayrlabilir."(U1)

"Program için sürenin uygun olduğunu düs̈̈̈n̈̈yorum. İzleyenleri sıkmadan bilgiler renkli bir sekilde aktarimis." (U4)

"Süre konusunda ögrenci dikkatini dağgtmadan iqleyen herkesin bir şeyler kapabileceği düzeyde kisizi sıkmadan bir eğitim program hazırlanmıs.” (U5)

"TRT'de yaymlanan eğitim programlarmm süresi kisileri sikmayacak bir uұunlukta olduğu için izllenme oranm bence artırmaktadır.” (U11)

"Konularn ortalama süresi iyiydi. Uzun olursa daha sıkıcı olurdu. Zaten içerik zayıf olduğu için süreyi uzatmak anlamsiz olurdu.” (U16)

"TRT" de yaymlanan programlar süre olarak bence uygun. Ne çok uzun ne de çok kisa. Böyle olması izleyenlerin sikılmadan konu hakekında bilgi sabibi olmasın kolaylastoryor.” (U18)

"Süre iyi gibi ancak biraz. uzatılabilecek bölümler var. Örneğin, biyoloji ögretim programında 2 ders saati konusu olan bakterilerin 5-10 dakikallk bir zaman diliminde verilmesi haliyle yetersiz oluyor." (U21)

"Süresi yeterli. Ama çevre, anatomi, sistemler gibi bazı biyoloji konularna da yer verilmeli." (U30)

"Sürenin uzunluğu gayet uygun. Daha uzun olsaydı izleyenlerin sıkılmasi söz konusu olabilirdi. Daha kisa olsaydr, anlatılan konunun anlasılması zorlasabilirdi.” (U31)

"Ë̆gitim programinin süresi ne ögrenciyi sikacak kadar uzun ne de heveslerini kiracak kadar kisa. Süre yeterli." (U32)

Aşağıda TRT’de yayınlanan “Gerçek Hayatta Ne İşimize Yarayacak?” eğitim programında konuların işlenişi hakkında uzmanların görüşlerinden örnekler yer almaktadır.

"Bazı bölümlerde katılımolar seviyeyi ayarlamakta sorun yaşarken bazılarmın ise sunum konusunda vasat olduğu söylenebilir.” (U2)

"Bazı bölümlerde açılama yapan uzmanlarn konuyu zuevkli bir sekilde açkladı̆g görüsündeyim. Günlük hayat ile ilişkilendirilebilecek birçok örnek veriliyor.” (U4)

"Daha çok güncel konulara yer verilmis. Programm adından da anlaşılabileceği gibi ögrencinin günlük hayatta karşılaşacăğ sorunlar ve merak edeceği konularla alakalı sunumlara, uðman görüslerine yer verilmis. Konular kişiyi sıkmadan fakat kazanımlara göre yüzeysel kalınarak en basit ve en yüzeysel şekilde anlatılmıs. Bu nedenle konunun içindeki daha baskea çok önemli yerlere değinilmeden geçilmiş.” (U5) 
"Konu çok eğlenceli işleniyor. Fakat seçilen użmanlarm bą̧larnm biraz daha eğlenceli olması isleyisi daha zevkli ve ögretici kulacaktur.” (U6)

"Konunun işlenişinde ĕgitimdeki yakından uzăga ilkesi kullanuldĭ̆ için daha olumlu sonuclar vermektedir. Bireyler konu işlenirken en yakınndan bir örnek olmasi ve daha sonra diğer örneklere gidilmesi konuya olan ilginin artmasın ve daha kolay anlaşılmasın sağlamaktadır.” (U11)

"Ekrana gelen resimler sekiller amaca uygun konuyu destekler yönde. Konularn laboratuvar vb. ortamlarda islenmesi konu ile bütünlük sağlamıs." (U12)

"Benim izlediğim videolardaki siralara göre konusacak olursak; özelden genele ya da genelden özele geçis veya 9.sinfftan 12.sinifa doğru bir geçis olmadiğın düsünüyorum.” (U15)

"Konunun işlenişi başarll. Yani işin uzmanlarna gidilip konuyu onlardan birebir dinleme

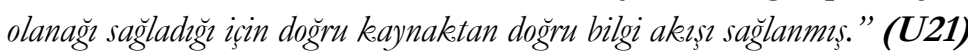

"Kazanmlar bazında değerlendirildiğinde kazanımlar karşılamadı̆̆ görüsündeyim. Konunun işlenişi zayif kalmıs.” (U27)

"Bazı programlar sıkucı olabilecek kadar tekdüze olsa da bazı programlar daha güncel ve hayata dair örnekler ile konular eğlenceli ve anlaşılır şekilde inceliyor.” (U28)

"İnsanlara soru sorularak açklanması başarlidir. İceriğin sunumunda uzmanlara danışılması uygun olmuş.” (U30)

"Konu teorik bilgiden çok öneriler ile günlük yaşantımı ile ilişkilendirilmis. Bu da konular ögrencilerin hatırda tutma düzeylerinde önemli bir kısım.” (U32)

"Özellikle 11.Bölümdeki skeci çok basarlı buldum. Bu yöntem kazanmlarm daha kolay ve daha kalıcı bir şekilde elde edilmesini sağhyor. Bu yöntemin diğer kazanımlar için de uygulanmasın beklerim.” (U34)

"Bilgi almak isteyen her birey için konu işlenis tarz̨ güzel. Yani görsel ve işitsel olarak etkileyici ve kahci olduğunu düsünüyorum." (U35)

"Başlangzcta soru ile giris gayet güzel. Sonraki anlatım yöntemi ise birazyetersiz:" (U39)

"Daha gelismis tekniklerle sunum yapulabilir. Animasyonlar gelistirilebilir. Görsel yönden daha zengin olursa tekdüzelikten, sikuculiktan siyrlabilir.” (U40)

Aşağıda TRT’de yayınlanan “Gerçek Hayatta Ne İşimize Yarayacak?” eğitim programı ile ilgili diğer görüş ve önerilerden örneklere yer verilmektedir.

"Günlük yaşamda ne işe yarayacak konusu aslinda bence çok ilgi çekici. Genel olarak ögrencilerin de dilinde olan bir cümledir aslinda "Bu ögrrendiğgmiz ne işimize yarayacak” sorusu. Bu soru ögrenciler açısından ilgi çekici olmasına rağmen konunun işlenişinin ilgi çekiciliğini arka planda burakır nitelikte olmasina sebep oldü̆unu düsünüyorum. Konunun işlenişi żenginleştirirse içeriğin ilgi cekiciliğinin daha verimli kullanulabilmesi sağlanabilir"." (U7)

"Programlar sadece genc ve çocuklara yönelike olmamalidır. Yetiskin bireylere de hitap etmelidir. Hayat boyu ögrenme dikekate alonmalidrr.” (U11)

"Ortaögretim ve ilköğretim program kazanımlar daha çok dikeate almarak programlar bažılanabilir. Bu sayede ögrencilerin bu programlardan daha çok fayda sağlaması sağlanabilir. Animasyon, canlandırma ve görseller yine ögrenciler için önemli. Bunun disında yetişkinlerin de izleyip yararl bilgiler kazanması için balkın görüslerine ve ögrenmek istediklerine kulak verilmelidir. Bu sayede insanlarn daha fazla ilgisini çekebilir." (U13)

"Tarafsız bir gözle değerlendirdiğimde eğer bir konu hakekında bilgi sahibi olmasaydım, bu program iəledikten sonra gerçek bayatta ne işe yaradiğ konusunda pek bir şey ögrenemezdim. Yine bu konunun ögrretilmesinin gereksiz olduğu düs̈̈ncesini korurdum! Sunucu oldukeça sempatik, bu nedenle ögrencilerin yaş grubuna göre programa ilgi çekmeyi artırabilir.” (U16)

"Biyolojinin diğer konularna da yer verilmeli." (U30)

"Bu tür programlarn tanıtımınn daha çok yapulması ve hatta okullar ile is birliği yapularak. derslerde de eğitim materyali olarak kullanılmasi gerektiği kanısındayım.” (U31) 


\author{
"Belirtilen eksiklikler dikekate almirsa programin amacma uygun, yeterli ve yararl olacağm \\ düsünüyorum. Ayrnca ögretmenler açısından da faydalı bir kaynak. olacaktır.” (U32) \\ "Giriş etkinliği amaçl ve yeterli saynlabilir. Ama programun daha da zenginleștirilmesi gerekli. \\ Ortaögretimde seviyesi iyi ögrencilere program çok basit kalmıs.” (U33) \\ “Bu programlar brans ögrretmenlerinin görïsleri almarak bazurlanabilir." (U35) \\ "Yetersiz bir program. Öğretmeye dayali değil. Kağıttaki sorularla çok bağımsı̨, konu anlatum. \\ Soru ile çok bağımsı fazla bilgi kalabaliğ yapılan açıklamalar var.” (U39)
}

\title{
4. TARTIŞMA VE SONUÇ
}

Bu çalışmada, TRT OKUL kanalında yayınlanan “Gerçek Hayatta Ne İşimize Yarayacak?” adlı eğitim programının ortaöğretim biyoloji dersi öğretim programının kazanımlarına ulaşmada ne kadar etkili olduğunun belirlenmesi amaçlanmıştır. Eğitim içerikli bu televizyon yayınının doğrudan doğruya öğretim programlarının hedeflerini kazandırmak gibi bir amacının olmadığını belirtmekte fayda bulunmaktadır. Ancak bu gibi programların öğrenciler başta olmak üzere toplumun her kesimine yönelik bilgilendirme amacı bulunmaktadır. İlgili literatürde bu gibi TV programlarının özellikle öğrencilerin akademik gelişimlerine etkisini değerlendirmeyi amaçlayan çalışmalar olmasına rağmen toplumun farklı kesimlerine hitap eden pek çok çalışmaya da rastlanmaktadır. Çalışmalardan örnek olarak; öğrencilerinin TV izleme sürelerinin hayat bilgisi dersindeki başarılarına etkisi (Güney, 2008); konuşma eğitimine TV'nin etkisi (Göçen, 2011); kitle iletişim araçlarının öğrencilerin sınıf içi davranışlarına etkisi (Ülkü, 2011); TV programlarının okul öncesi çocuklarının gelişimine etkisi (Arslan, 2010; Calverta ve Kotler, 2003; Can, 1995; Christakis, Garrison, ve Thakkar, 2006; Lackner, 1997; Serhatlıoğlu, 2006); ergenlik dönemi gelişiminde TV'nin etkisi (Balantekin, 2009; Dinç, 2010); çifçi eğitiminde TV'nin etkisi (Aydın, 2009; Ceylan, 2010); TV programları ve çocuklardaki şiddet davranışlanı (Şen, 2008; Yıldırım, 2008); TV’de yayınlanan sanat programlarının sanat eğitimine katkısı (Yüceer, 2007) şeklinde vermek mümkündür. Ancak bu programların bir dersin kazanımlarına uygunluğuna yönelik olarak değerlendirildiği bir çalışmaya rastlanmamıştır. Dolayısıyla aşağıda tespit edilen bu araştırma sonuçları literatüre önemli katkılar sağlayacak niteliktedir.

Araştırmaya katılan 42 uzmanın, "Gerçek Hayatta Ne İşimize Yarayacak?” programının MEB ortaöğretim 9. sınıf biyoloji dersinin 30 kazanımından oluşan formda 26 kazanımın tamamen ya da çoğunlukla kazandırılmasına katkı sağlamadığını ifade ettikleri belirlenmiştir. Bu sonuca göre, "Gerçek Hayatta Ne İşimize Yarayacak?” programının MEB ortaöğretim 9. sınıf biyoloji dersi kazanımlarını sağlamada yetersiz olduğu sonucuna ulaşılmışıı. Aynı şekilde araştırmaya katılan 42 uzmanın "Gerçek Hayatta Ne İşimize Yarayacak?” programının MEB ortaöğretim 10. sınıf biyoloji dersinin 24 kazanımdan oluşan formda sadece 2 kazanımı sağlamada kısmen de olsa uygunluk gösterdiği, uzmanların diğer kalan 22 kazanımın kazandırılmasına uygun olmadığı görüşünde oldukları belirlenmiştir. Bu bilgiler ışığında, TRT OKUL kanalında yayınlanan “Gerçek Hayatta Ne İşimize Yarayacak?” programının MEB ortaöğretim 10. sınıf biyoloji dersi kazanımlarını sağlamada başarılı olmadığı sonucuna ulaşılmıştır. Diğer taraftan araştırmaya katılan 42 uzmanın, “Gerçek Hayatta Ne İşimize Yarayacak?” programının MEB ortaöğretim 11. sınıf biyoloji dersinin 37 kazanımından oluşan formda 33 kazanımı sağlamada uygun olmadı̆̆ 
görüşünde oldukları tespit edilmiştir. "Gerçek Hayatta Ne İşimize Yarayacak?” programının MEB ortaöğretim 11. sınıf biyoloji dersi kazanımlarının büyük çoğunluğunu sağlamadığı sonucuna ulaşılmıştır. Son olarak araştırmaya katılan uzmanların, "Gerçek Hayatta Ne İşimize Yarayacak?” eğitim yayınını izleyip MEB ortaöğretim 12. sınıf biyoloji dersi öğretim programı kazanımlarına sağlamaya ilişkin verdikleri cevaplarda, programın 47 kazanımdan oluşan ölçme aracında sadece 3 kazanımın gerçekleştirilmesinde etkili olduğu, geriye kalan 44 kazanımın gerçekleştirilmesinde programın yetersiz olduğu görüşünde oldukları belirlenmiştir. Bu sonuçlarla, "Gerçek Hayatta Ne İşimize Yarayacak?” programının MEB ortaöğretim 12. sınıf biyoloji dersi kazanımlarını sağlayamadığı sonucuna ulaşılmıştır.

$\mathrm{Bu}$ değerlendirmeler ışığında incelendiğinde uzmanların görüşlerine göre; "Gerçek Hayatta $\mathrm{Ne}$ İşimize Yarayacak?” programının MEB ortaöğretim 9., 10., 11. ve 12. sınıf biyoloji dersi kazanımlarını izleyen öğrencilere kazandırmakta yeterli olmadığı belirlenmiştir. Eğitim içerikli bu televizyon yayınının doğrudan doğruya öğretim programlarının hedeflerini kazandırmak gibi bir amacının olmadığ1 belirtilmektedir. Ancak bu kadar maddi harcama ve emek karşıllığında izleyicilere ulaşan bu programın pek çok derse yönelik içeriği kapsaması ancak belli bir akademik kriterlere göre hazırlanmamış olması oldukça önemli bir eksiklik olarak görülebilir. Çünkü eğitim faaliyetlerinin ihtiyaç duyduğu ve yetersiz kaldığ1 durumlarda televizyon önemli bir destek olmaktadır. Örneğin; Nijerya'da okul, öğretmen ve ulaşım sorunları nedeniyle köylere televizyon alıcıları yerleştirilerek, videokasetler ile çocuklara Fransızca öğretilmiş, bunun sonucunda çocukların sınavlarda başarılı olduğu görülmüştür (Turam, 1996). İzleyicilerin akademik olarak eğitimleri konusunda oldukça önemli olan TV yayınlarının akademik kriterlere göre hazırlanarak verilmesi istenen mesajın daha akademik hale dönüştürülmesinde oldukça önemli ve etkili olacaktır.

Araştırmada elde edilen diğer önemli sonuçlardan bazıları ise şu şekilde tespit edilmiştir; Araştırmaya katılan uzmanların çoğunluğunun "Gerçek Hayatta Ne İşimize Yarayacak?” programında işlenen konuların biyoloji dersi öğretim programına içerik açısından uygun olduğunu ancak içeriğin kazanımlar açısından uygunluk göstermediğini düşündükleri belirlenmiştir. Diğer taraftan "Gerçek Hayatta Ne İşimize Yarayacak?" programında, her bir konuya ayrılan sürenin uygun olduğunu ve konuların açıklanmasının da yeterli olduğunu göstermektedir. Son olarak; uzmanların programdaki konunun işlenişi hakkındaki görüşleri ise, uzmanların çoğunluğunun yöntem ve teknikler açısından görsellere, şekillere yer verilmesinin; konuların laboratuvar gibi ortamlarda aktarılmasının; birincil kaynaktan bilginin alınmasının; konuların günlük hayat ile ilişkilendirilmesinin ve hayat boyu öğrenmeyi desteklemesi açısından uygun olduğunu ifade ettikleri görülmektedir. Ancak uzmanlardan bazıları, daha çok görsele ve animasyonlara yer verilmesi gerektiği, sadece okullarda derse girişte merak uyandırmak amaçlı kullanılabilecek bir yayın olduğu; tek düze anlatımdan uzak kalınması gerektiğini vurguladıkları tespit edilmiştir. Kitle iletişim araçlarının habercilik, dünyada ve Türkiye'deki gelişmeleri hızlı ve doğru şekilde topluma aktarmak görevleri gibi bireyleri ve toplumu eğitmek yönünde önemli özellikleri bulunmaktadır. Geri kalmıs ülkeler, eğitim sorunlarının çözümünde direkt bu araçları kullanmayı hedef alırken; gelişmiş ülkeler, bu araçlardan eğitimde yardımcı araç olarak yararlanmayı temel almaktadır (Khodabandeh, 2010). Türkiye'de TV eğitim 
programları MEB derslerine ait kazanımlarla uyumluluk gösterebilirse toplumda ihtiyacı olan her kesimden bireylerin kullanımı için uygun hale getirilebilir.

Sonuç olarak; TRT tarafindan hazırlanan eğitim programlarının MEB tarafindan hazırlanan ders programlarını daha fazla dikkate alarak hazırlanmasında yarar vardır. Böylece büyük emek verilerek ve harcamalar yapılarak hazırlanmış olan bu programlar eğitim alanında daha nitelikli amaçlara yönelik hizmet etmiş olacaklardır. Aşağıda konuyla ilgili önerilere yer verilmektedir;

1. "Gerçek Hayatta Ne İşimize Yarayacak?” gibi programların konularının günlük hayatla ilişkilendirildiği, hayat boyu öğrenmeye katkıda bulunacak ve MEB ders programlarını da destekleyen programlar şeklinde hazırlıkları artırılabilir.

2. TRT ile MEB arasında kurulacak işbirliği ile hem öğrenciler hem de öğretmenler için faydalı olacak televizyon programları hazırlanabilir. Bu programlar doğrudan kazanımları sağlamaya yönelik programlar şeklinde düzenlenebilir.

3.Bireysel ve toplumsal gelişim yönünde araştırmacılar eğitim içerikli televizyon yayınlarını inceleyip yayınların izleyicilerin eğitiminde ne yönde etkili olduğunun belirlenmesini amaçlayan çalısmalar planlanabilir.

4.Bu araştırmada, "Gerçek Hayatta Ne İşimize Yarayacak?” adlı eğitim programının ortaöğretim biyoloji dersi öğretim programının kazanımlarına ulaşmada ne kadar etkili olduğuna ait veriler uzmanların görüşleriyle elde edilmiştir. Bu araştırma öğrencilerin ve velilerin katılımıyla da yapılabilir.

5.“Gerçek Hayatta Ne İşimize Yarayacak?” programı içeriği ilköğretim ve ortaöğretimde yer alan diğer derslere ait öğretim programları kazanımlarını sağlaması yönünden de incelenebilir.

\section{KAYNAKÇA}

Arslan, Ş. (2010). Televisyon Reklamlarmm Okul Öncesi Dönem Cocuklarmm Tüketici Davranıslarna Etkileri. Yayımlanmamış Yüksek Lisans Tezi. Gazi Üniversitesi Eğitim Bilimleri Enstitüsü, Ankara.

Atay, M. \& Öncü, E. (2003, 13-15 Ekim). Elektronik Bakıc Televišyon. 1.Uluslararası Çocuk ve İletişim Konferansı: Milenyumda Çocuk ve İletişim. İstanbul.

Aziz, A. (1975). Televisyonun Yetiskin Eğitimindeki Yeri ve Önemi. Ankara: TODAİE Yay.

Aziz, A. (1982). Radyo ve Televiogyonla Eğitim. Ankara: Ankara Üniversitesi Eğitim Fakültesi EFAM Yay.

Aydın, D (2009). TRT'nin Yaygen Eğitim Amaşh Televisyon Yaymlarmm (2004-2008) Kamu Hižmeti Yayınclluğ Açssından Değerlendirilmesi. Yayımlanmamış Yüksek Lisans Tezi. Marmara Üniversitesi Eğitim Bilimleri Enstitüsü, İstanbul.

Balantekin, Y. (2009). 10-14 Yaş Arası Cocuklarda Televišyon Bağımlilŭğ Üžrine Bir Araştırma. Yayımlanmamış Yüksek Lisans Tezi. Uludağ Üniversitesi Sosyal Bilimler Enstitüsü, Bursa.

Bassey, M. (1999). Case Study Research in Educational Settings. USA: Open University.

Bilgin N (2006). Content Analysis Techniques and Case Studies in Social Sciences. Ankara: Siyasal Publication.

Büyüköztürk, Ş., Kiliç Çakmak, E., Akgün, Ö. E., Karadeniz, Ş. \& Demirel, F.(2008). Bilimsel Araştrrma Yöntemleri. Ankara: Pegem Yayınları.

Calverta, S. L. \& Kotler, J. A. (2003). Lessons from Children's Television: The Impact of the Children's Television Act on Children's Learning. Applied Developmental Psychology 24 (2003)275-335. 
Can, A. (1995). Okul Öncesi Çocuklara Yönelik Televisyon Programlar Ị̇inde Çiz̨gi Filmlerin Çocuklarn Gelişimine ve İletişimine Etkileri. Yayımlanmamış Doktora Tez). Marmara Üniversitesi Sosyal Bilimler Enstitüsü, İstanbul.

Ceylan, S. (2010). Güneydoğu Anadolu Bölgesi'nde Cifți Eğitim Aracı Olarak Televiąyonun Etkin Kullammı ve Bereketin Adı GAP Ömeği. Yayımlanmamış Yüksek Lisans Tezi. Gazi Üniversitesi Sosyal Bilimleri Enstitüsü, Ankara

Christakis, D.A., Garrison, M.M. \& Thakkar, R.R. (November, 2006). Educational TV has Positive Effects on Toddlers and Preschoolers.

http://www.sheknows.com/parenting/articles/8028/educational-tv-has-positive-effects-on-toddlers-andpreschoolers adresinden, 02 Şubat 2014 tarihinde alınmıştır.

Cohen, L., Manion, L. \& Morrison, K. (2007). Research Methods in Education (6th ed.). New York, NY: Routledge.

Coyne, I. (1997). Sampling in Qualitative Research. Purposeful and Theoretical Sampling: Merging or Clear Boundaries? Journal of Advanced Nursing, 26 (3), 623-630.

Creswell, J.W. (2012). Educational Research: Planning, Conducting and Evaluating Quantitative and Qualitative Research (4th ed.). Boston: Pearson.

Denzin, N.K. \& Lincoln, Y.S. (1996). Strategies of Qualitative Inquiry. London: Sage Publications.

Dinç, B. (2010). Ergenlike Döneminde Beden Imgesinin Gelișimi Üzrerine Aile, Akran ve Televiąyon Etkilerinin Incelenmesi. Yayımlanmamış Doktora Tezi. Gazi Üniversitesi Eğitim Bilimleri Enstitüsü, Ankara.

Ertürk, Y.D. \& Akkor, G.A. (2006). Çocuğınuгu Televisyona Teslim Etmeyin. Ankara: Nobel Yayın Dağıtım.

Given, L.M. (Ed.) (2008). The Sage Encyclopedia of Qualitative Research Methods. Sage: Thousand Oaks, $C A$.

Göçen, G. (2011). Televizyonun Konuşma Eğitimine Etkileri. Yayımlanmamış Yüksek Lisans Tezi. Sakarya Üniversitesi Eğitim Bilimleri Enstitüsü, Sakarya.

Güney, K. (2008). İlkögrretim Birinci Kademe 3. Simf Öğrencilerinin Televizyon İzleme Sürelerinin Hayat Bilgisi Dersindeki Başarlarna Etkisi. Yayımlanmamış Yüksek Lisans Tezi. Hacettepe Üniversitesi Sosyal Bilimler Enstitüsü, Ankara.

Karataş, K. (Ekim, 2010). Kitle İletişim Araçlar İle Eğitim.

http://kayhankaratas75900.blogcu.com/kitle-ilesim-ve-egitim/6838776 adresinden, 25.11.2013 tarihinde alınmıştır.

Khodabandeh, S. (2010). Cevre Sorunlarn Açısından Küreselleșme Sürecinde Kitle İletişim ve Cevre İçin Eğitimin Önemi. Yayımlanmamış Doktora Tezi. Ankara Üniversitesi Sosyal Bilimler Enstitüsü, Ankara.

Lackner, T.M. (1997). Enhancing Children's Educational Television with Design Rationales and Justifications. University of California, Los Angeles.

Lichtman, M. (2010). Qualitative Research in Education. Los Angeles: Sage Publications, Inc.

McMillan, J.H. (2000). Educational Research: Fundamentals for the Consumer. New York: Longman.

Miles, M.B. \& Huberman, A.M. (1994). Qualitative Data Analysis. Thousand Oaks, CA: Sage.

Özgen, M. (1985). Radyo ve Televişyonda Eğitim Yaymları. C. Kavcar (Edit.) Kitle İletişim Araçları ve Eğitim Sempozyumu. Ankara: Ankara Üniversitesi Eğitim Bilimleri Fakültesi Yay.

Patton, M.Q. (1990). Qualitative Evaluation and Research Methods. USA: Sage.

Serhatlioğlu, B. (2006). Televiagyon Programlarmin Okul Öncesi Eğitim Kurumuna Devam Eden 5-6 Yass Grubu Çocuklarmm Zibin ve Dil Gelişimini Etkileme Biçimlerine Yönelike Öğretmen ve Veli Görüslerinin Belirlenmesi. Yayımlanmamış Yüksek Lisans Tezi. Fırat Üniversitesi Sosyal Bilimler Enstitüsü, Elazı̆̆.

Şen, Ş. (2008). Ortä̈gretim Ögrrencilerinin Suç Yönelmesinde Kitle İletişim Araçlarmin Rolü (İstanbul İli Bağcular İlgesi Örneği). Yayımlanmamış Yüksek Lisans Tezi. Beykent Üniversitesi, Sosyal Bilimler Enstitüsü, İstanbul. 
Ülkü, E. (2011). Kitle İletişim Araçlarmm Öğgrencilerden Simf içi Davranışlarna Etkisi Üz̧erine Öğretmen Görïşleri. Yayımlanmamış Yüksek Lisans Tezi. Çanakkale Onsekiz Mart Üniversitesi Sosyal Bilimler Enstitüsü, Çanakkale.

Turam, E. (1996). 2000'li Yillara Doğru Türkiye'de TV. İstanbul: Altın Kitaplar1 Yayınevi.

Varol, N. (1997). Radyo ve Televisyonun Eğitim Amaçl Kullanımı. Türk Cumhuriyetleri ve Asya Pasifik Ülkeleri Uluslararası Eğitim Sempozyumu. Elazığ 24-26 Eylül 1997.

Yildırım, E. (2008). Cocuk ve Televisyonda Şiddet: 5 Yasındaki Cocuklarn Anne- Babalarmm Televisyondaki Siddet İserikli Yayınlarm Davranıslar Üzerindeki Etkilerine İlișkin Görïsleri. Yayımlanmamış Yüksek Lisans Tezi. Gazi Üniversitesi Eğitim Bilimleri Enstitüsü, Ankara.

Yıldırım, A. \& Şimşek, H. (2006). Sosyal Bilimlerde Nitel Araştırma Yöntemleri. Ankara: Seçkin Yayıncılık.

Yüceer, B. (2007). TRT'de Yayınlanan Sanat Programlannm Sanat ve Eğitimine Katkısı. Yayımlanmamış Yüksek Lisans Tezi. Gazi Üniversitesi Eğitim Bilimleri Enstitüsü, Ankara.

\section{Citation Information}

Yıldırım, A. \& Ekici, G. (2016) TRT Kurumu'nun TRT Okul Kanalındaki Yayınlarının Ortaöğretim Biyoloji Dersi Öğretim Programı Kazanımları Açısından Analizi. Dicle Üniversitesi Ziya Gökalp Eğitim Fakültesi Dergisi, 28, 189-214. 